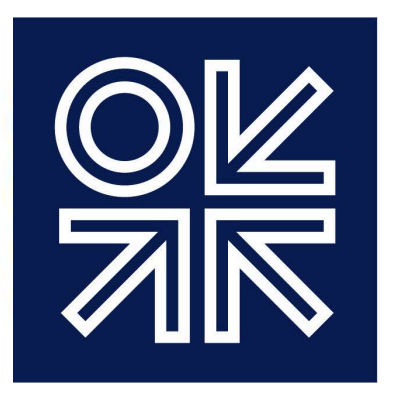

THE OXFORD

INSTITUTE

FOR ENERGY

STUDIES

March 2015

\title{
Evolution of gas pipeline regulation in Russia:
}

Third party access, capacity allocation and transportation tariffs

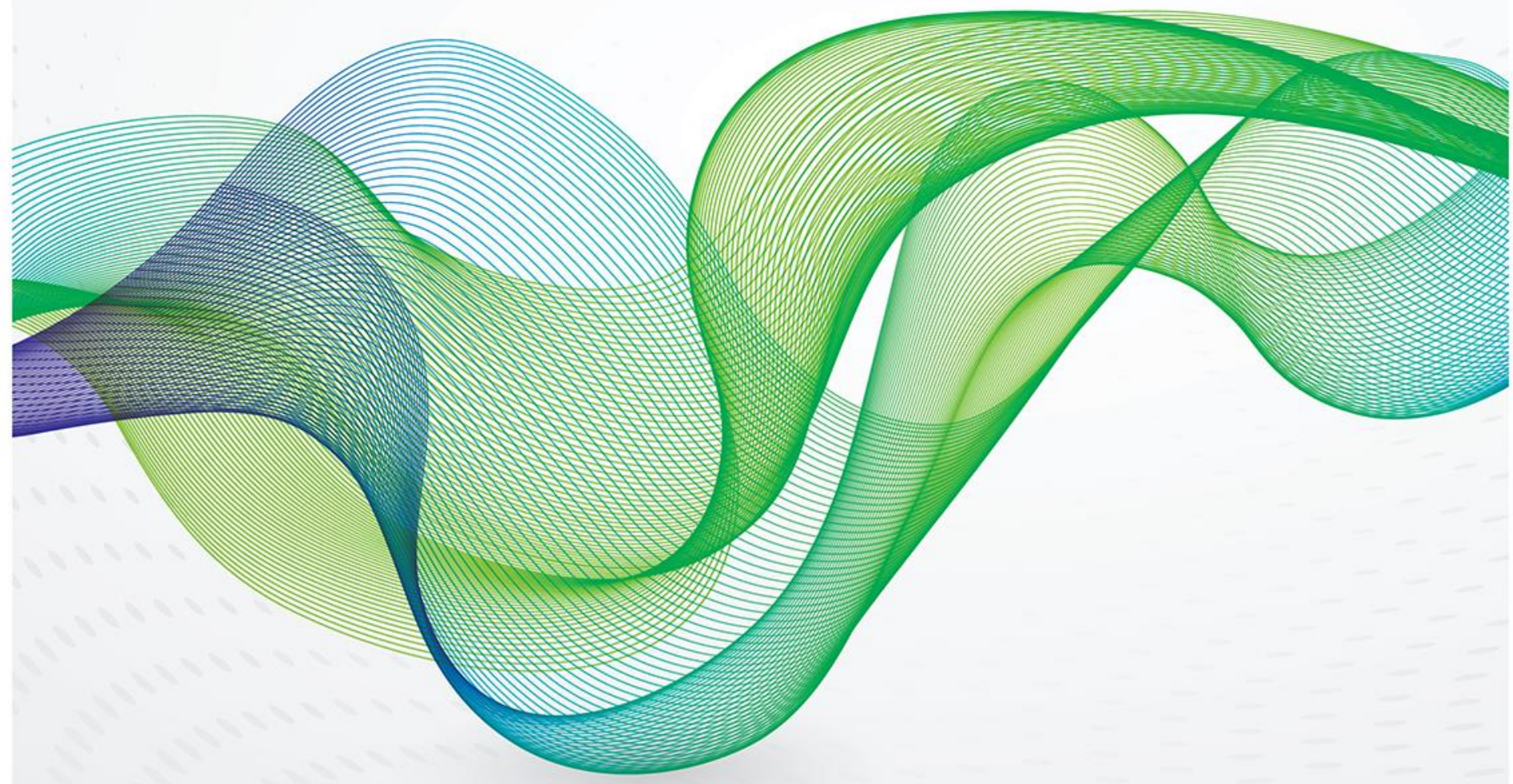



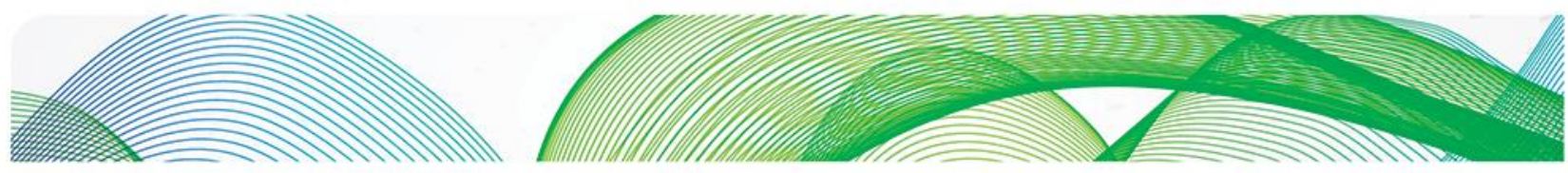

\section{O는}

The contents of this paper are the authors' sole responsibility. They do not necessarily represent the views of the Oxford Institute for Energy Studies or any of its members.

Copyright $\odot 2015$

Oxford Institute for Energy Studies

(Registered Charity, No. 286084)

This publication may be reproduced in part for educational or non-profit purposes without special permission from the copyright holder, provided acknowledgment of the source is made. No use of this publication may be made for resale or for any other commercial purpose whatsoever without prior permission in writing from the Oxford Institute for Energy Studies.

ISBN 978-1-78467-024-5 


\section{Contents}

Summary iv

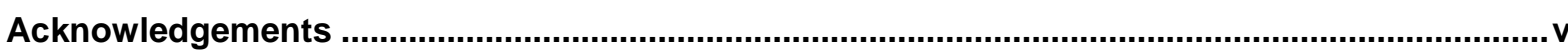

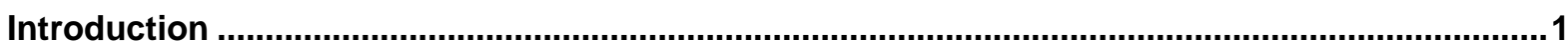

1. The Russian Federal Gas Supply System: the UGS and non-UGS systems.........................2

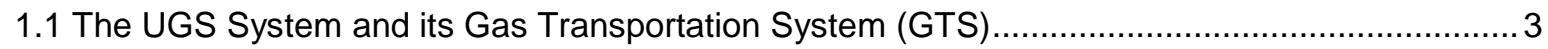

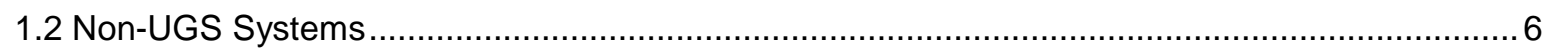

1.3 Investment Framework for Incremental and New Capacity in UGS and non-UGS Systems ..... 10

2. Third-Party Access to UGS and non-UGS Systems: access and allocation rules ..............12

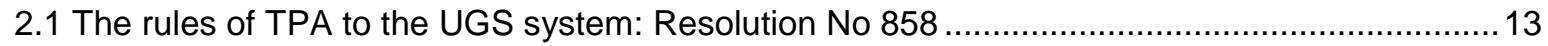

2.2 Non-UGS Systems: TPA to the Eastern Gas Programme pipelines (case studies) ..................17

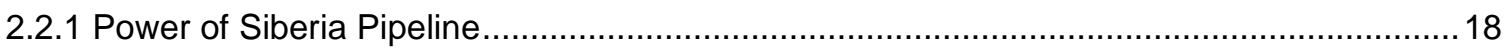

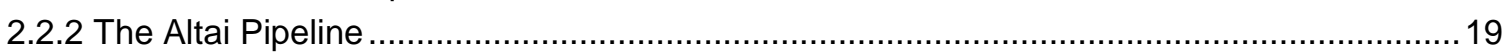

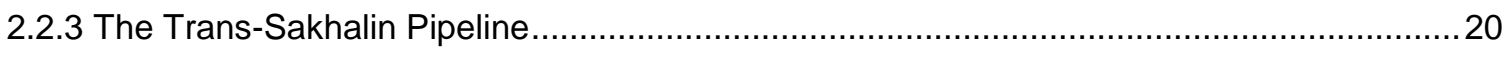

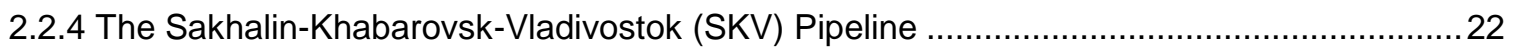

2.3 Draft Rules on Non-Discriminatory Access to all High-Pressure Pipelines ................................23

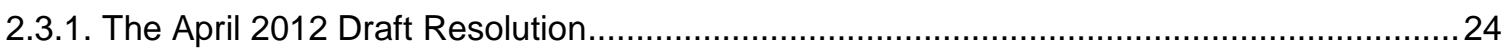

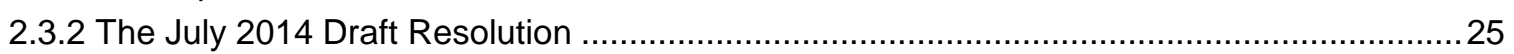

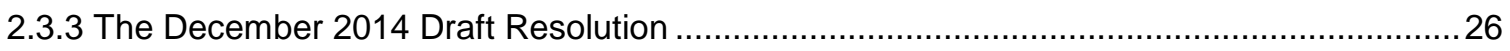

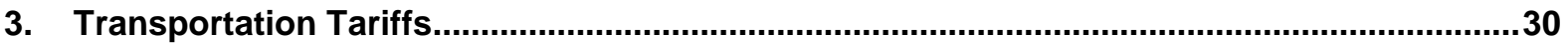

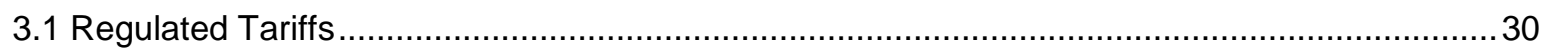

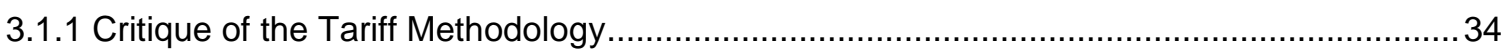

3.2 Tariffs Charged to Gazprom for Transportation of its Own Gas Sold at Regulated Prices ........34

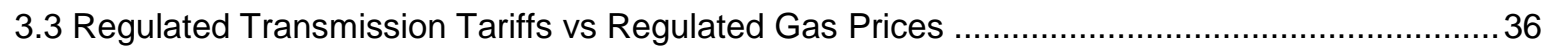

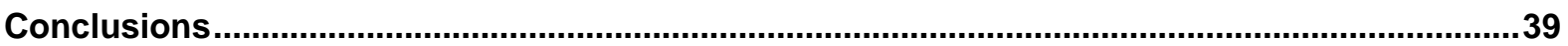

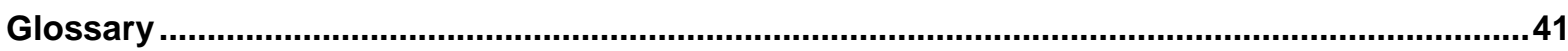

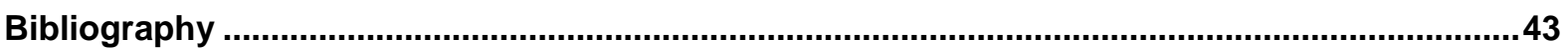

\section{Figures}

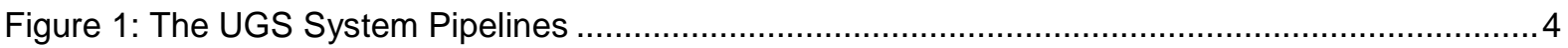

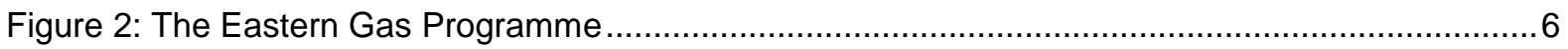

\section{Tables}

Table 1: Gazprom's High-Pressure Gas Transmission Network (GTS), 31 December 2013 ..............6

Table 2: Gazprom's Transport of its Own and Third Party Gas, 2008-13 …..................................16

Table 3: Average Level of Transportation Tariffs Charged by Gazprom to Third Parties ....................33

Table 4: Internal Transportation Tariffs charged by Gazprom to its Transmission Companies, 2005 and 2009 

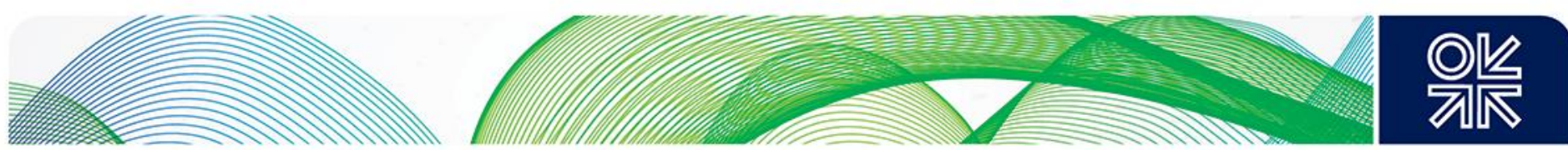

\section{Preface}

The Russian Federation has the second largest gas transportation network in the world (after the US). While liberalisation of gas transportation in OECD countries has been the subject of a significant number of publications and regulatory documents, there is relatively little to read on the changes in the Russian transportation system which have become increasingly significant in the 2010s. The OIES Gas Programme has published a great deal on the Russian gas industry over the past several years. However, a notable omission in our output (and other publicly available commentary in English) has been a lack of detail on liberalisation and regulation of gas transportation, and the evolution of gas transportation tariffs and tariff design. The principal reason for this is the need to be able to access relatively complex legal/regulatory texts in the Russian language, and the regulatory and tariff design expertise required to interpret them.

Katja Yafimava's paper substantially expands on her previous published work. ${ }^{1}$ It has been informed by her research on EU gas regulation, ${ }^{2}$ as well as her participation as an expert on the EU-Russia Gas Advisory Council, which has exposed her to the complexities of the legal/regulatory regimes for gas in both Europe and the Russian Federation. As in the case of the EU, the Russian regulatory regime is very much in transition, with a constant ebb and flow of draft resolutions, as key stakeholders attempt to influence the authorities and obtain access to the network on advantageous terms. A major change in the availability of transportation over recent years has been a growing surplus of capacity caused by stagnant or falling demand in all of the west-facing markets where Russian gas is sold. Eastern Russia has become a new competitive battleground for non-Gazprom resource-holders seeking to monetise (currently stranded) gas through new export-oriented pipelines.

With many new developments in both western and eastern Russian networks, regulation of network access and tariffs is likely to continue to develop rapidly, and it would not be surprising if this paper needed to be updated on a regular basis.

Jonathan Stern

Oxford, March 2015

\footnotetext{
See Henderson and Pirani (2014), pp.141-153.

2 Yafimava (2013).
} 

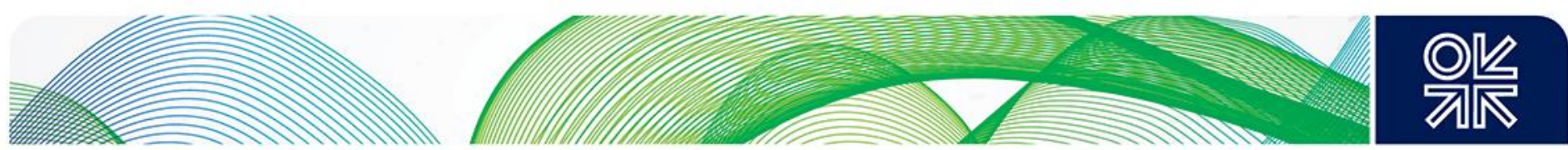

\section{Summary}

Russia has been reforming its domestic gas transportation regime since the mid-2000s and achieved significant progress, the extent of which has been largely underestimated by European observers. This is not surprising as the latter have traditionally viewed the lack of ownership unbundling and the existence of Gazprom's pipeline export monopoly as the sole criteria for measuring the reform's success. While signaling that the reform may still have far to go, it has, in its first stage, successfully laid down the structural foundation for a non-discriminatory access regime by introducing legal unbundling and, in its second stage, established a legal/regulatory framework for non-discriminatory access. The reform's relative success has most evidently manifested itself in the dramatic increase of (non-Gazprom) third party gas transportation through the UGS (Unified Gas Supply) system which has taken place since the late 2000s.

The existing framework remains insufficiently developed both in scope (e.g. non-applicability to nonUGS systems, storage and LNG infrastructure) and content (e.g. significant room for discretion in choice of routes for third party gas and capacity allocation in the event of capacity deficit). The new draft framework, currently under discussion in government, aims to address these problems.

Transportation tariff design has also evolved significantly. The introduction in 2005 of new zonal tariff methodology (used for calculation of regulated tariffs charged to third parties for transportation of their gas through the UGS system) addressed some third party concerns, although questions remain about Gazprom's choice of routes for third party gas and the methodology's cost-reflectivity, not least because of its lack of transparency.

From the Russian state's point of view, the aim of domestic gas market reform - including the reform of the gas transportation regime - is to establish a level playing field for Gazprom and non-Gazprom parties in order to ensure the optimal development of the domestic gas sector and the Russian economy as a whole, while preserving the country's competitive position as an exporter to both European and Asian gas markets. At present, these aims are to be achieved by increasing direct government involvement and strengthened FTS (Federal Tariff Service) and FAS (Federal Antimonopoly Service) oversight. However, should these measures fail, then more radical measures might be required. In such a situation it is not inconceivable that abolition of the UGS system indivisibility principle, with subsequent Gazprom ownership unbundling, might take place with (potentially) the state becoming the owner of both the UGS and non-UGS networks. In early 2015, as this paper is being completed, this seemed a 'last resort' measure which was not under consideration by the authorities. 

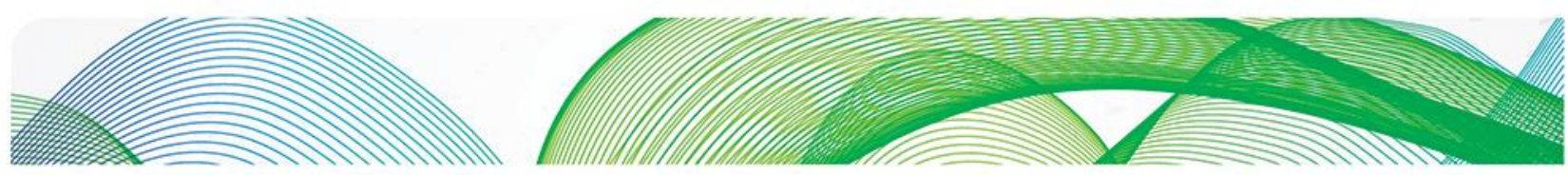

\section{䬧}

\section{Acknowledgements}

While researching and writing this paper - which has proved a challenge due to the complexity of Russian gas regulation and its rapidly evolving nature - I was privileged to have been able to count on the advice, support and encouragement of my OIES colleagues. My special thanks go to Jonathan Stern for his generosity with sharing his time and expertise by commenting on the working draft which has significantly improved its quality. I am also grateful to Howard Rogers and James Henderson for their valuable comments on the final draft. My conversations with many participants of the EU-Russia Gas Advisory Council have also been useful and I am grateful to all of them. I am also grateful to John Elkins for editing, Anita Gardiner and David Sansom) for designing the maps (Figure 1 and Figure 2 respectively, and to Kate Teasdale for administrative support. Responsibility for all the views expressed and all the conclusions reached is solely mine. 

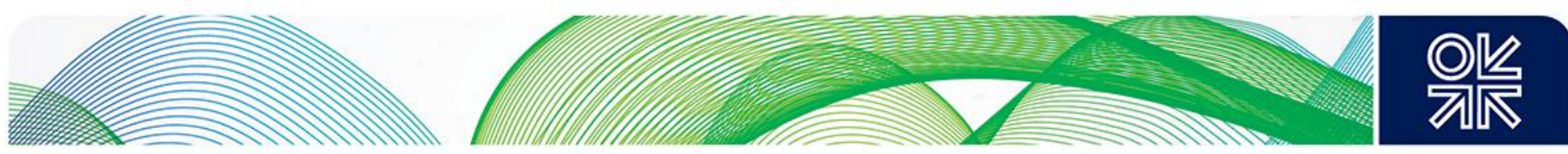

\section{Introduction}

The Russian gas transportation regulatory regime is an important subject, which should be of interest to the European research and policy making community, not least as its evolution will have significant implications not only for the Russian domestic gas market, but also for Russian gas exports to European (and Asian) markets.

Due to historical, political and geographical reasons, the Russian gas industry - and hence gas transportation regime - has developed differently from its European counterparts in respect of its legal, physical and commercial organization. In 2015, Gazprom (formerly the Soviet Ministry of Gas Industry) is still a dominant player in all segments of the domestic gas value chain. Much of this dominance comes from Gazprom's ownership of Russia's major gas supply system - the Unified Gas Supply (UGS) system (see Section 1) - which gives it an exclusive right to transport third party gas through the UGS transportation network. However, despite its continuing dominance, as of the late 2000s Gazprom's position in the domestic market has been weakening, with non-Gazprom third party gas taking an increasing share of the market. This was achieved by means of improved enforcement of non-discriminatory access to the UGS transportation network (using regulatory and anti-monopoly instruments) and was a direct result of the Russian government's determination to ensure that (lower cost) third party gas can compete successfully with Gazprom's gas in the domestic market. Access to non-UGS networks has remained more problematic, as demonstrated by continuing disputes between Gazprom and third parties (especially Rosneft), specifically in respect of pipelines built under the Eastern Gas Programme (EGP) (see Section 1.2).

As third party usage of UGS and non-UGS pipelines is set to increase, the challenge of developing an adequate regulatory framework, which would establish a level playing field for Gazprom and nonGazprom parties in order to ensure the optimal development of the domestic gas sector and the Russian economy as a whole, while preserving the country's competitive position as an exporter to both European and Asian gas markets, will become increasingly urgent thus providing an important rationale for this paper. 

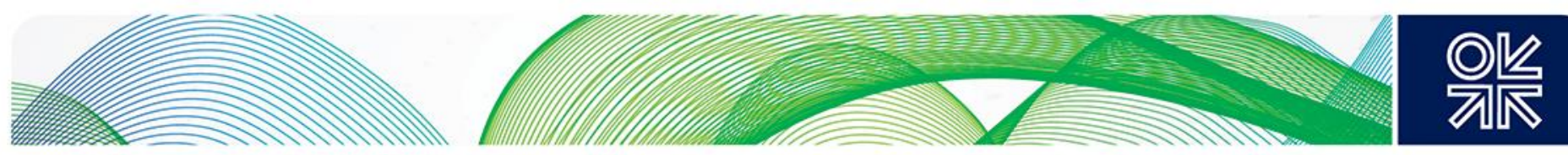

\section{The Russian Federal Gas Supply System: the UGS and non-UGS systems}

The Russian Federal gas supply system includes the following gas supply systems operating on Russian territory: the Unified Gas Supply (UGS) system, regional gas supply systems, gas distribution systems, 3 and independent organizations.

The UGS system is the main component of the Russian federal supply system; the Law on Gas Supply defines it as a "complex of technologically, organizationally and economically connected and centrally managed production, transportation, storage and supply objects", its division is forbidden by law ("the principle of indivisibility") (Art. 14). 4 The UGS system is exclusively owned by Gazprom.5 Under the Russian Law on Gas Exports the owner of the UGS system has an exclusive right to export gas in gaseous form (thus including pipeline gas but excluding LNG).6 As such, Gazprom effectively holds a monopoly on all pipeline gas exports; its monopoly to export LNG was abolished in 2013.7

A regional supply system is another component of the federal supply system, and is defined in the Law on Gas Supply as a "complex of technologically, organizationally and economically connected and centrally managed production, transportation, storage and supply objects which is independent from the UGS system".

An independent organization is another element of the federal supply system and is defined as, "an organization engaged in production and supply activities and is independent from the UGS system and regional supply systems' owners and from gas distribution systems" (Art. 2).

Thus the UGS system and regional supply systems are based on the principle of vertical integration as their definitions presuppose that a company that owns and/or manages them would be engaged not only in production and supply, but also in transportation and storage activities. ${ }^{8}$ This suggests that as long as the principle of UGS system indivisibility remains in place, any plans for breaking up Gazprom - the UGS system's exclusive owner - into production, supply and transportation divisions (discussed by the Russian government in the 1990s and the 2000s but postponed thereafter) could not be implemented.

\footnotetext{
${ }^{3}$ This paper only deals with issues of access to high-pressure pipelines, therefore gas distribution systems are not analysed.

${ }^{4}$ Federal Law "On Gas Supply in the Russian Federation" (hereafter the Law on Gas Supply) No 69-Ф3, 31 March 1999.

${ }^{5}$ For Gazprom ownership structure see http://www.gazprom.com/investors/stock/structure/

${ }^{6}$ Curiously Federal Law "On Gas Exports" No 117-Ф3, 18 January July 2006 as amended 30 November 2013 (hereafter the Law on Gas Exports) stipulates that it is the owner of the "unified gas supply system" - rather than the owner of the "Unified gas supply system" (capitalized), which holds the monopoly on pipeline gas exports. This is an important difference as the notion of "unified gas supply system" is a broader definition and might include supply systems which are currently not part of the UGS system. Here "unified gas supply system" could be interpreted as the supply system which could be formed once and if the Unified Gas Supply System will be connected with the regional supply networks in east Siberia and Far East thus forming a genuinely unified gas supply system.

${ }^{7}$ At the time of writing there are only two other companies - Rosneft and Novatek - which meet the criteria, set by the Law on Gas Exports, allowing these companies to export LNG.

${ }^{8}$ There is less clarity on the status of independent organizations: on one hand, they appear to be based on the ownership unbundling principle, as no engagement in transportation business is envisaged by the Law on Gas Supplies, on the other hand, ownership of gas transport networks by independent organizations is envisaged by the FTS tariff methodology.
} 

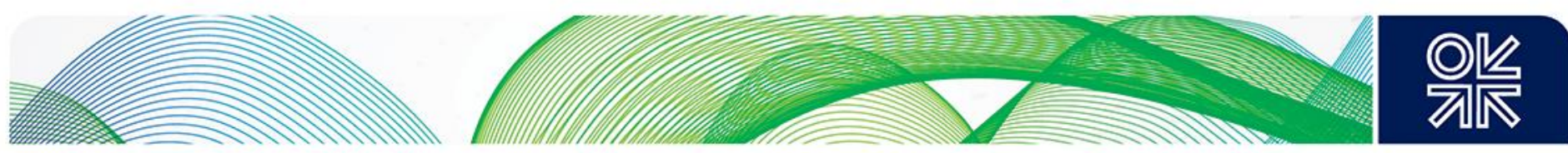

\subsection{The UGS System and its Gas Transportation System (GTS)}

The UGS system was created in the 1960s but grew up around the three main gas producing fields in the Nadym Pur Taz region of western Siberia (Medvezhye, Urengoy and Yamburg) and the UGS system Gas Transportation System (GTS) was designed to transport gas from these fields westwards and southwards to main centres of domestic consumption in the European part of Russia and for export to Europe (Figure 1). ${ }^{9}$ In 1991, when the USSR broke up, the UGS system lost those of its constituent parts which were located on the territories of former Soviet republics, including production assets in Central Asia and transportation and storage assets in the Baltics, Ukraine, Belarus and Moldova.

Its owner, Gazprom is obliged to operate, provide for expansion, reconstruction and modernisation as well as controlling the dispatching of gas (Art. 13). Also Gazprom has an exclusive right and responsibility to carry out technological and dispatch control of all systems connected to the UGS system irrespective of their ownership; owners of these systems with a connection agreement cannot take them out of operation without Gazprom's consent (Art. 14).

The gas transmission system (GTS) is a major part of the UGS system. In 2013, it comprised 168,900 $\mathrm{km}$ of high-pressure pipelines, 247 compressor stations (with a total capacity of $45.9 \mathrm{GW}$ ) and 26 underground storage facilities (with a working capacity of $70.4 \mathrm{bcm}$ ). ${ }^{10}$ The network is highly integrated through the use of multiple and parallel pipelines, interconnectors and storage. The GTS is responsible for transportation, storage and delivery of nearly all natural gas supplies in Russia (except for supplies to the Norilsk, Yakutsk and Sakhalin regions which are supplied via regional supply systems, see Section 2.2).

Gazprom's Moscow central dispatch centre controls and manages gas flows in the GTS. The GTS itself is managed by seventeen Gazprom Transgaz companies (gas transmission operators), wholly owned Gazprom subsidiaries, which hold 'network assets on the basis of long-term lease agreements with Gazprom'11 and transport gas throughout the country $(659.4 \mathrm{bcm}$ of gas was transported through the GTS in 2013). ${ }^{12}$ Each of these subsidiaries has some 8,000-9,000 km of pipelines with their zones of responsibility corresponding to the geographic boundaries of Russian regions. This structure effectively amounting to legal unbundling of transmission (although only accounting unbundling was required by law) - is the result of Gazprom's corporate restructuring reform embarked on in 2005. ${ }^{13}$ This reform has increased Gazprom's efficiency and also gone some way towards placating the Russian government, which at the time was discussing the possibility and necessity of ownership unbundling whereby Gazprom would be forced to sell off its GTS. Although ownership unbundling is no longer on the government's agenda (the issue was not mentioned during the June 2014 meeting of the Presidential Energy Commission, which was chaired by the Russian president Vladimir Putin and

\footnotetext{
${ }^{9}$ During the Soviet era all the gas produced in western Siberia was produced by Gazprom. However, in the post-Soviet period, third parties gained production rights in western Siberian smaller fields (due to Gazprom's inability and/or unwillingness to develop these fields in the 1990s) and by 2014 their share of domestic production reached $27 \%$. For a detailed overview and analysis of the UGS system see Stern (2005), pp. 35-38.

${ }^{10}$ Gazprom Annual Report 2013, http://www.gazprom.com///posts/60/660385/gazprom-annual-report-2013-en.pdf.

${ }^{11}$ Seliverstov and Gudkov (2012), p. 400.

12 Gazprom Annual Report 2013.

${ }^{13}$ Resolution No 1021, 29 December 2000 'On state regulation of gas prices and transportation tariffs in the Russian Federation'. See Glossary for definitions of various unbundling regimes.
} 

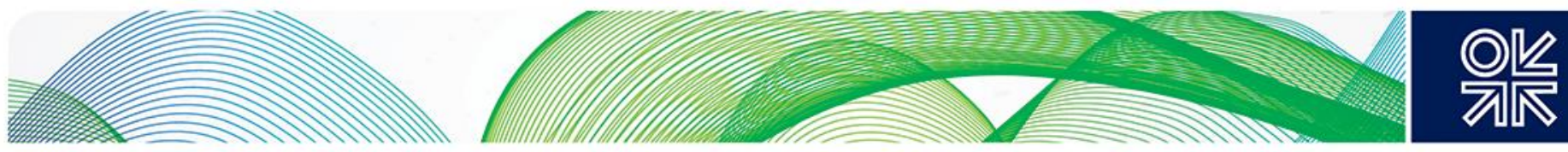

which mandated the government to develop a new concept of Russian gas market development ${ }^{14}$ ), legal unbundling laid down the structural foundation for a non-discriminatory access regime - the main objective of ownership unbundling. ${ }^{15}$

Figure 1: The UGS System Pipelines

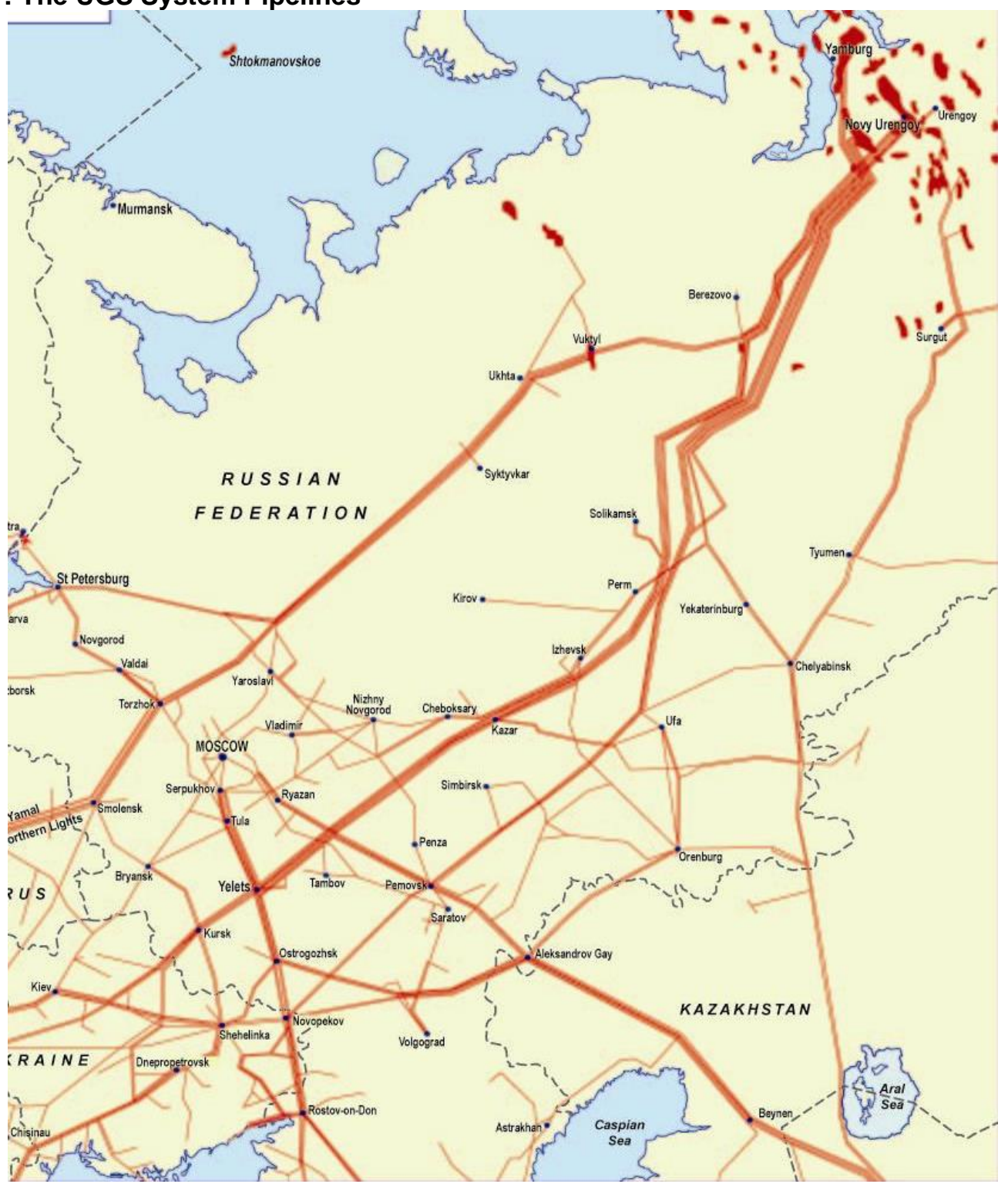

Source: OIES

Note: only the pipelines located on the Russian territory count as the UGS system pipelines

In the late 2000s - early 2010s Gazprom expanded the GTS by building new high pressure pipelines, mostly in conjunction with bringing on stream new fields on the Yamal Peninsula and creating new

\footnotetext{
${ }^{14}$ The meeting of the Presidential Commission on strategy for energy sector development and ecology security (transcript, in Russian), 4 June 2014, http://news.kremlin.ru/news/45831

${ }^{15}$ Stern (2005), pp. 184, 194-95; Gudkov and Seliverstov (2012), p. 402.
} 

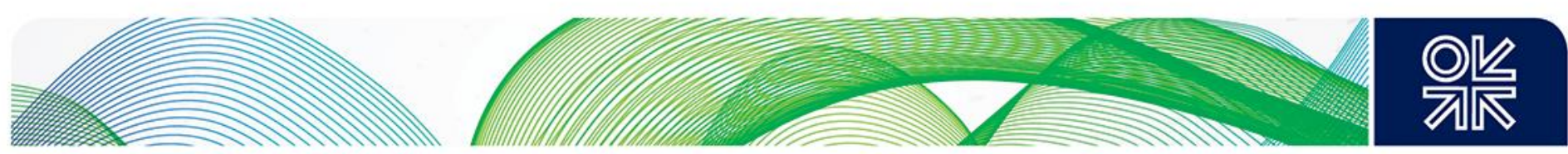

export corridors. In 2012 Gazprom completed expansion of the Gryazovets-Vyborg pipeline (intended for delivering gas for Nord Stream and north-west Russia) as well as construction of the SRTOTorzhok pipeline. Gazprom is also building the Bovanenkovo-Ukhta pipeline system, the first string of which began to operate in October $2012(1,240 \mathrm{~km})$, and the second line is under construction (expected to be completed in 2016). Also in 2012, Gazprom started construction of its Southern Corridor pipeline system, which is intended to supply gas for South Stream as well as to central and southern Russian regions; ${ }^{16}$ completion of its first string $(880 \mathrm{~km})$ is planned for 2015 , with the completion of the whole system $(2,506 \mathrm{~km})$ planned for late 2019 . Overall, some $703 \mathrm{~km}$ of new high pressure pipelines was commissioned in 2013. ${ }^{17}$

On December 1, 2014, the Russian president Vladimir Putin, speaking at a joint press conference with his Turkish counterpart, Recep Tayyip Erdoğan, announced that the South Stream project could not proceed 'under current conditions' due to the lack of construction permission from Bulgaria and unresolved issues with the European Commission (EC) over the Third Energy Package (TEP); ${ }^{18}$ he also announced that the project (later suggested to be re-named as 'Turkish Stream') will be redirected to Turkey for onward delivery of gas to the Turkish-Greek border. The Southern Corridor pipeline infrastructure, which was originally planned to carry gas for South Stream, would be used for carrying gas for Turkish Stream. ${ }^{19}$

Despite these recent additions, the major part of the GTS was built in the Soviet era. At the end of $2013,75.7 \%$ of pipes were more than twenty years old and only $12.5 \%$ were built during the past decade (Table 1). ${ }^{20}$ This is a direct result of Gazprom's underinvestment in GTS maintenance and refurbishment due to its financial difficulties in the 1990s: reportedly no more than $29 \%$ of the required funding was made available. ${ }^{21}$ Having recovered its financial position in the 2000s, Gazprom began to pay increased attention to the technical condition of the GTS; in March 2011 a comprehensive upgrade programme for 2011-15 was adopted. In the 2010s the level of electronic diagnostics of trunk pipelines has been increasing (reaching $22,550 \mathrm{~km}$ in 2013) whereas the level of in-line diagnostics has decreased (to $21,500 \mathrm{~km}$ in 2013); the length of pipeline subject to capital repairs was increased up until 2012 (when it reached 2,487 km) but decreased significantly in $2013(1,818 \mathrm{~km})$. It is not clear whether the 2013 decline reflects a reduced need for such repairs due to the improved state of the network or budget constraints. Overall the measures taken in the 2010s appear to have improved the reliability of the network with Gazprom reporting reduced fault levels and interruptions (8 faults reported in 2013 compared to 32 in 2002, with on average one fault per 20,000 km). ${ }^{22}$ However, it is not clear whether these measures have increased the level of productivity of the network which in 2002 stood at around 9\% below its design capacity. ${ }^{23}$

\footnotetext{
16 'Joint press conference with President of the Turkish Republic' (transcript, in Russian), http://www.kremlin.ru/news/47126

${ }^{17}$ Gazprom, Gazprom in Figures 2009-2013: factbook, http://www.gazprom.com/f/posts/55/477129/gazprom-in-figures-20092013-en.pdf

${ }^{18}$ Specifically in respect of TPA, ownership unbundling and transportation tariffs. For more detail on the TEP and Russian problems associated with it, see Yafimava (2013).

${ }^{19}$ Stern, Pirani and Yafimava (2015).

${ }^{20}$ Gazprom Annual Report 2013.

${ }^{21}$ Mitrova (2009), p. 414.

22 Gazprom Annual Report 2013.

${ }^{23}$ Stern (2005).
} 

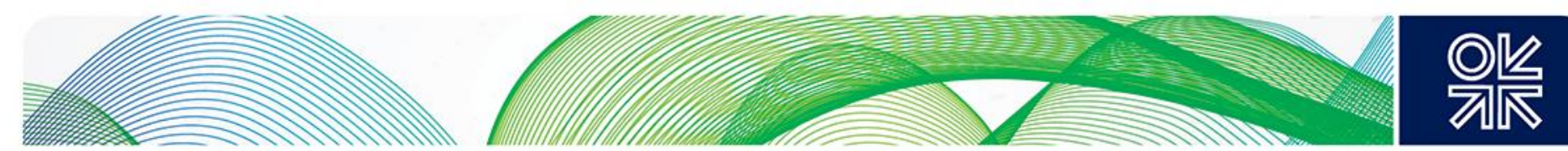

Table 1: Gazprom's High-Pressure Gas Transmission Network (GTS), 31 December 2013

\begin{tabular}{|l|l|l|}
\hline Year Since Construction & Length, thousand $\mathrm{km}$ & \% of Total \\
\hline Up to 10 years & 21.1 & 12.5 \\
\hline $11-20$ years & 20.0 & 11.8 \\
\hline $21-30$ & 56.5 & 33.4 \\
\hline $31-40$ & 41.7 & 24.7 \\
\hline $41-50$ & 19.7 & 11.7 \\
\hline Over 50 years & 9.9 & 5.9 \\
\hline TOTAL & 168.9 & 100.0 \\
\hline
\end{tabular}

Source: Gazprom Annual Report 2013, p. 47.

\subsection{Non-UGS Systems}

The UGS system covers the European part of Russia excluding eastern Siberia and the Far East regions. ${ }^{24}$ In September 2007 the Russian government entrusted Gazprom with the responsibility to coordinate and implement the Eastern Gas Programme (EGP), ${ }^{25}$ part of the government's wider initiative aimed at accelerated development of eastern Siberia and the Far East (Figure 2). ${ }^{26}$

\section{Figure 2: The Eastern Gas Programme}

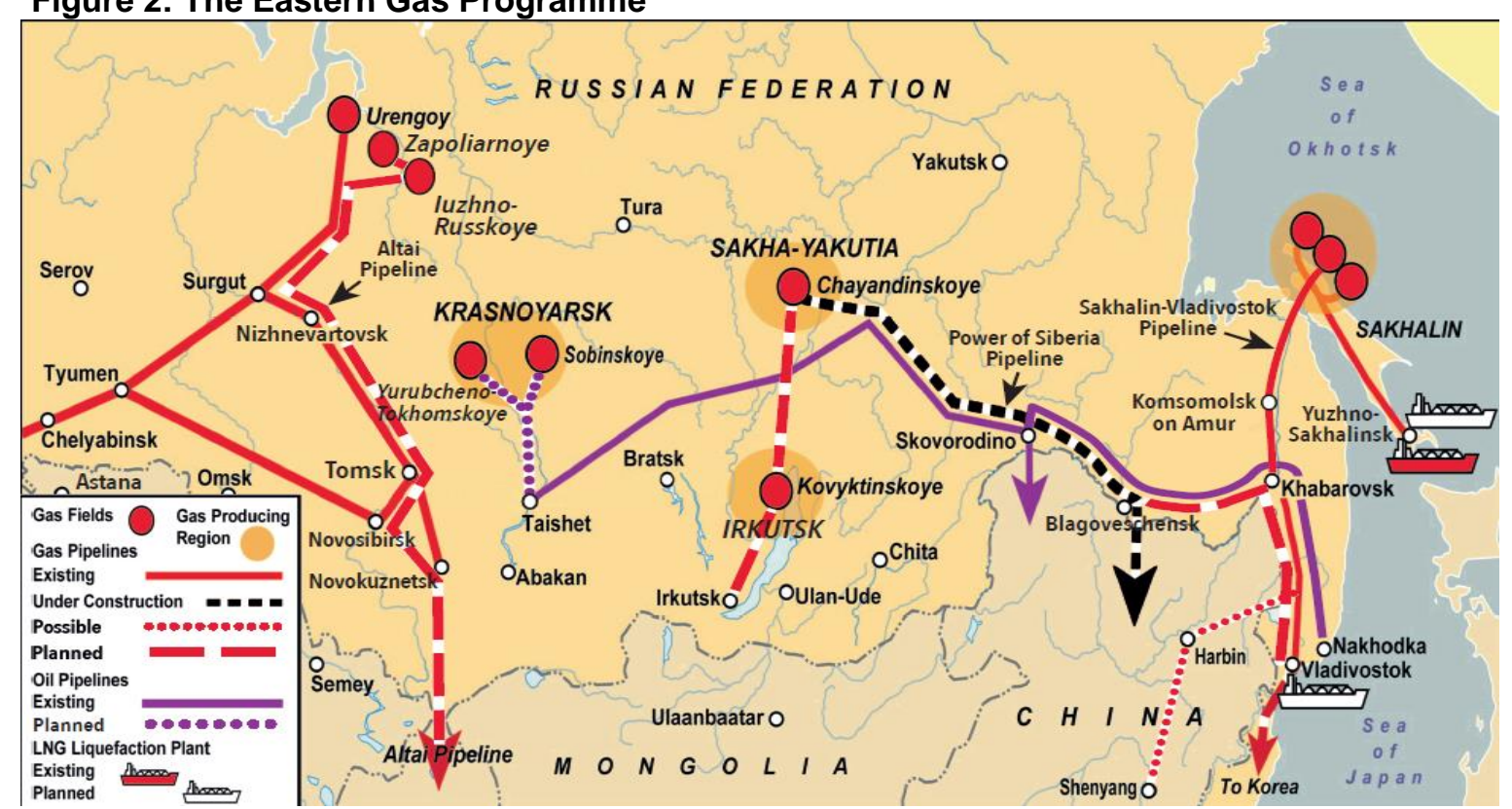

Source: OIES

\footnotetext{
${ }^{24}$ For the list of pipelines constituting the UGS system's GTS see the General Plan for Development of the Russian Gas Sector 2030 (draft) (in Russian) (“General Plan for Gas 2030”),

http://www.energyland.info/files/library/112008/7579b56758481da282dd7e0a4de05fd1.pdf

${ }^{25}$ Programme for development of the unified system for gas production, transportation and supply in eastern Siberia and the Far East taking into account possible gas exports to the markets of China and other countries in the Asia-Pacific region (henceforth "The Eastern Gas Programme"), see Eastern Gas Programme (2007).

${ }^{26}$ In the attempt to reverse the depopulation and economic degradation of the region, which borders with China, the fastest growing economy in Asia, see Stern and Bradshaw (2008), pp. 245-249.
} 

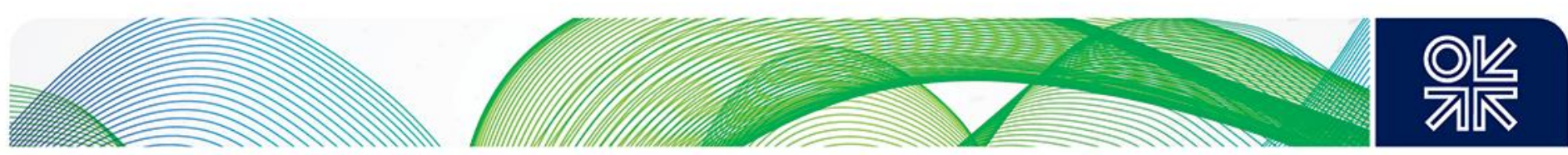

The EGP is based on four gas producing centres: the Sakhalin centre (focusing on Sakhalin 1,2 and 3 projects in the north of Sakhalin ${ }^{27}$ ), the Yakutia centre (focused on the Chayanda field), the Irkutsk centre (the Kovykta field) and the Krasnoyarsk centre (the Sobinsk and Yurubcheno-Tokhomsk fields). The EGP originally envisaged that the Sakhalin 1 project would supply gas to the Sakhalin and Khabarovsk regions (inter alia via the existing pipeline system) with the Sakhalin-KhabarovskVladivostok (SKV) system to be used for supplies to the Primorsk region and for exports to China and South Korea. ${ }^{28}$ This was to be followed by gas from Sakhalin 3 and from Yakutia, including construction of a pipeline from Yakutia to Khabarovsk (Power of Siberia). Gas from Sakhalin 2 was designated for exports to Asia from the LNG plant in Prigorodnoye in the south of Sakhalin Island and delivered there via the Trans-Sakhalin pipeline. Gas from both the Irkutsk and Yakutia centres was also envisaged to be used for domestic consumption. Importantly, the EGP also stipulates that exports to Asia will be carried out on the basis of a "single export channel", ${ }^{29}$ while honouring existing PSAs (i.e. Sakhalin 1 and 2). ${ }^{30}$

Given that eastern Siberia and the Far East regions have only limited potential for increased domestic consumption, securing gas export sales into neighbouring Asia, where the potential for gas demand growth is significant - both as pipeline gas and LNG, is crucial for the EGP to be commercially viable. Commercial realities - such as the conclusion of Sakhalin 2 contracts and delays with Sakhalin 1 contracts as well as delays on Gazprom's contracts to supply China (see below) - have had a significant impact on EGP implementation. By 2014, several regional supply networks had been developed, though not quite in the order envisaged by the EGP. The Sakhalin 2 project became a frontrunner, with the Trans-Sakhalin pipeline transporting its gas to the first and currently only Russian liquefaction plant at Prigorodnoe in the south of Sakhalin. This started operation in 2010 and could be expanded ${ }^{31}$ to allow exports to a number of Asian countries; the Sakhalin-Khabarovsk-Vladivostok (SKV) pipeline is used to transport Sakhalin 2 and 3 gas for domestic consumption.

The development of Sakhalin 1 (expected to be the original EGP frontrunner) has experienced delays (mostly due to the inability of the Sakhalin 1 major partners - Rosneft and ExxonMobil - to agree on the price at which to sell its gas to Gazprom at the time when the latter held the monopoly not only on pipeline but also on LNG exports). ${ }^{32}$ But it progressed significantly in 2013-14 while demanding access to the Trans-Sakhalin pipeline to transport its gas to Rosneft's (planned but yet to be built) Far East LNG plant in Sakhalin. Both Gazprom and Rosneft are also present in Sakhalin 3 (but not in the same part of it), with Rosneft demanding that Gazprom provide gas and transportation through the SKV pipeline for supplies to Rosneft's (planned but yet to be built) Eastern Oil and Chemical Company (EOCC) petrochemical plant in Nakhodka near Vladivostok. An additional pipeline between Vladivostok and Nakhodka would be required to connect the EOCC plant with the SKV pipeline (see Section 2.2.4).

Construction of gas pipeline(s), which would connect production centres in eastern Siberia with China (potentially the biggest market targeted by the EGP) had long been held up by Gazprom's inability to agree the price of gas with its Chinese counterpart, Chinese National Petroleum Company (CNPC).

\footnotetext{
${ }^{27}$ See Glossary for more detailed information on Sakhalin 1, 3 and 3 projects. For history of the Sakhalin projects see Stern and Bradshaw (2008), pp. 225-239.

28 The Sakhalin-Khabarovsk pipeline already existed and was extended to reach Vladivostok thus forming the SKV pipeline.

${ }^{29}$ Whereby gas would be exported by a single exporting company.

${ }^{30}$ Sakhalin 1 is the Far Eastern LNG project, while Sakhalin 2 is owned and operated by the Sakhalin Energy joint venture, see Glossary for detail.

${ }^{31}$ Gazprom, 'In February 2014 Gazprom and Shell signed the memorandum-roadmap to prepare FEED documents for expansion', press release, 30 September 2014, http://www.gazprom.com/press/news/2014/september/article202504/

${ }^{32}$ Until late 2013 Gazprom held the monopoly on LNG exports, which has now been abolished, with Rosneft and Novatek also getting the right to export LNG.
} 

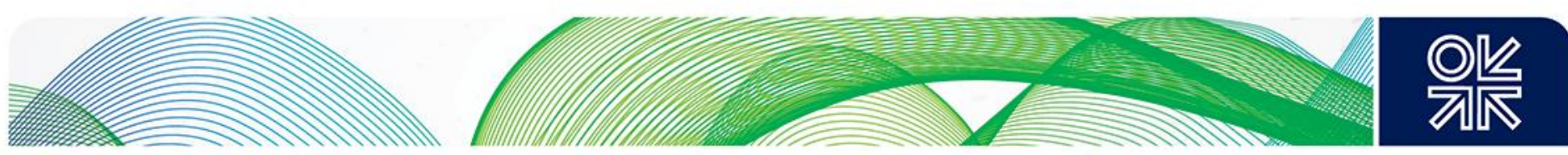

Initially the negotiations focused on exports via the Altai pipeline ('western route'), which would allow exports from the developed fields in western Siberia and on the Yamal peninsula to north-west China, ahead of the development of eastern Siberia fields. ${ }^{33}$ In contrast, China had originally favoured the Power of Siberia pipeline route ('eastern route'), which would connect east Siberian fields with major consumption centres in north east China. Eventually, in May 2014, Gazprom and CNPC finally signed a sale and purchase contract for deliveries to start in 2018-20 through the Power of Siberia pipeline. Negotiations on the western route also intensified with the intention expressed to sign a second contract for exports via the Altai pipeline in 2015. ${ }^{34}$ By concluding a contract with China for pipeline gas and with other Asian buyers for Sakhalin 2 LNG, Gazprom has developed an export model allowing it to sell gas via a direct link to China, and provide market flexibility by gaining access to the Pacific coast and the Asian markets. ${ }^{35}$

Importantly, none of the existing or planned regional supply systems in eastern Siberia and the Far East are connected to each other or to the UGS system. Potentially, such connections could be created, although not until the mid-2020s at the earliest. If constructed, the Altai pipeline could connect to the UGS system, and it is not inconceivable that it could then be connected with the Power of Siberia pipeline, as well as with the SKV and Trans-Sakhalin pipelines. Importantly, this possibility appears to have been confirmed by President Putin, who noted that a pipeline network in the Far East and Siberia would allow to 'connect the European part of the gas pipeline system to the Eastern one' thus giving Russia 'a great advantage of regulating the flows consistent with the situation of the global market - either to the West [...] or to the East'. ${ }^{36}$

In fact, both the EGP and the (draft) General Plan for Gas - 2030 envisaged that the east Siberian and Far Eastern production centres could become gradually connected by pipeline to form an eastern gas supply system. In turn, this system could then be connected to the UGS system thus expanding the latter throughout the entire country and forming a genuinely unified gas supply system which would cover both the European and non-European parts of Russia. Clearly, Gazprom is keen for these newly constructed system(s) to become part of the UGS system, of which it is the sole owner. Indeed, Gazprom's CEO, Alexei Miller, speaking at the $3^{\text {rd }}$ International Gas Forum in October 2014, stated that Gazprom intends to "create a unified gas supply system for entire Russia through creation of the new transport system in the east and its subsequent connection with the existing system". ${ }^{37}$ Here 'a unified gas supply system' could be understood as the supply system which could be formed if and when the UGS system would be connected with the regional supply networks in east Siberia and the Far East. ${ }^{38}$

Should this vision be upheld by the "General Plan for Gas - 2035", 39 significant investment in new pipelines as well as the rules regulating their construction and usage would be required to realize this

\footnotetext{
${ }^{33}$ Henderson (2014).

${ }^{34} \mathrm{Ibid}$. Interestingly, in March 2015 unconfirmed reports appeared suggesting that the Altai pipeline could be built ahead of Power of Siberia, 'Russia could postpone gas pipe to China touted by Putin - sources', Reuters, 18 March 2015, http://uk.reuters.com/article/2015/03/18/russia-gas-china-idUKL6NOWI48420150318 

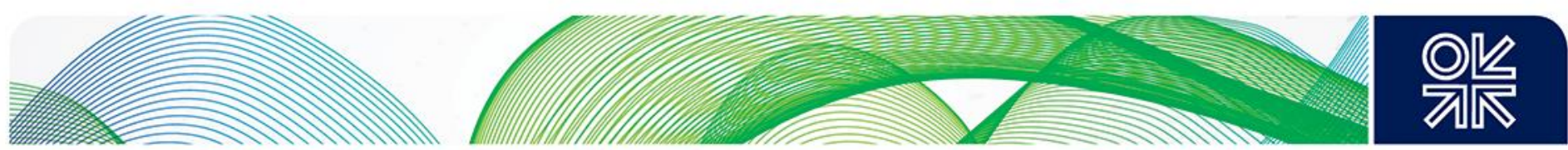

vision. The issues of investment in, and access to, such new capacity, as well as the tariffs to be paid for access, will require resolution at the government level as the current legal/regulatory framework does not address them (see Section 2).

\section{Possible effect of the 2014 EU and US sanctions on the EGP implementation}

In 2014, in response to Russia's annexation of Crimea and its alleged role in continuing instability in eastern Ukraine, the EU and the US introduced several rounds of administrative and financial sanctions, directed at Russian companies. ${ }^{40}$ Although the EU sanctions have not directly targeted the Russian gas sector, they created an environment of uncertainly, complicating the sector's access to long term finance and technology. Importantly all major Russian oil and gas companies, including Rosneft and Novatek, are on the EU and US sanctions lists. Gazprom is not on the EU sanctions list because it is the exclusive exporter of Russian pipeline gas to Europe ${ }^{41}$ but it is (effectively) on the US sanctions list. ${ }^{42}$ The adverse impact of sanctions on the Russian economy was further compounded by a dramatic fall (40\%) in oil prices in the second half of 2014 .

Undoubtedly both the sanctions and the oil price decline will have an impact on the Russian government's priorities for the country's gas sector in "The General Plan for Gas -2035" and specifically the EGP. The increasingly difficult political and economic environment might force the government to adopt a more coordinated approach towards the EGP implementation, with a view to minimizing the cost, the degree of reliance on western (and hence potentially sanctionable) LNG technology, and the degree of reliance on sanctioned Russian companies. Thus the government might want to strengthen Gazprom's role as the EGP coordinator, Gazprom being the only nonsanctioned (and in all likelihood unsanctionable by the EU) Russian gas company. Furthermore, the government might decide to prioritize pipeline gas over LNG exports, as the former does not involve any (significant) reliance on western technology. Consequently, the government might be forced to halt the Far East 'LNG plant race' between Gazprom-led Vladivostok LNG and Rosneft-led Far East LNG plants. According to Russian deputy energy minister, Kirill Molodtsov, the government's decision on selecting the priority LNG project on Sakhalin Island is expected to be made in the middle of $2015 .{ }^{43}$ Instead, the government could support a more commercially sensible option of Sakhalin 2

mid-2015, 'New draft of the General Plan for Gas to 2035 will be prepared by December',

http://www.rbc.ru/rbcfreenews/20140227142124.shtml

${ }^{40}$ Council Regulation (EU) No 960/2014, Council Regulation (EU) No 833/2014.

${ }^{41}$ Stern (2014), p. 5. Notably, the then former European Council President, Herman van Rompuy, noted in July 2014 that there was an 'emerging consensus' among EU governments that 'the measures in the field of sensitive technologies will only affect the oil sector in view of the need to preserve EU energy security'. See 'EU edges to economic sanctions on Russia but narrows scope', Reuters, 25 July 2015 http://www.reuters.com/article/2014/07/25/us-ukraine-crisis-eu-idUSKBNOFU0Y820140725

${ }^{42}$ Although under the US sanctions regime a project which has the potential to only produce gas (as opposed to a project that has the potential to produce oil and gas) is not under sanctions, the regime effectively puts Gazprom under US sanctions given that no one can be sure that they will be lending/selling to a project that will only produce gas. For a useful overview of EU and US sanctions see Mann and Denton (2014).

43 'Rosneft, Gazprom not confirming out-of-court agreement on Sakhalin-2 pipeline - regulator', Interfax Weekly, 12 December 2014. 

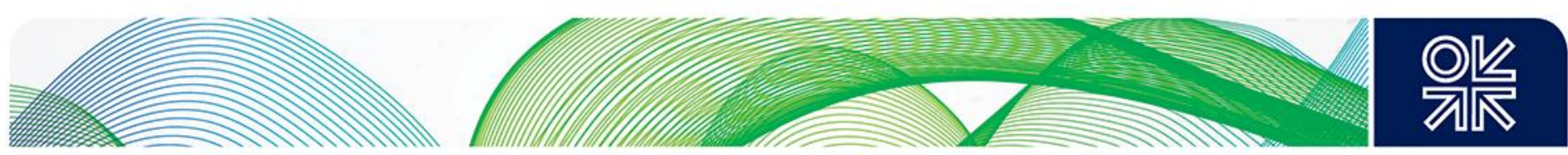

expansion. ${ }^{44}$ The Sakhalin 2 expansion appears least threatened by future sanctions on LNG technology since Sakhalin 2 is an already existing (as opposed to new) project. ${ }^{45}$

This revised approach would confirm Gazprom's leading role in coordination and implementation of the EGP. For its part, Gazprom has long been advocating a complex approach towards gas development in the Far East, calling for the formation of 'a single balance of Sakhalin gas' 46 which would allow for optimization of production and transportation thus improving the position of Sakhalin LNG in the increasingly competitive Asian LNG markets. Agreement, which has proved impossible to achieve thus far due to domestic politics and the animosity especially between Gazprom and Rosneft, might be reached under pressure of the worsening economic situation, which limits the government's and the companies' freedom of financial manoeuvre and requires adoption of the lowest cost solution.

Should the government's EGP strategy be amended in the light of sanctions as described above, the importance of developing a legal/regulatory framework governing the rules of access of third parties to both UGS and non-UGS system capacity, will become even more urgent. A level playing field between Gazprom and third parties, at least in the domestic (if not necessarily the export) market, and the assurance of a strengthened role of third parties in the domestic market might be seen as necessary compensation, especially as third parties' ambitions of becoming LNG exporters are curtailed (see Section 2).

\subsection{Investment Framework for Incremental and New Capacity in UGS and non-UGS Systems}

The existing legal framework has failed to establish a clear set of rules for investment in construction of incremental and new pipeline capacity in both UGS and non-UGS systems. In respect of the UGS system Gazprom, as its owner, has financed its development through payment of regulated transmission tariffs by users. ${ }^{47}$ The draft Law on Trunk Pipelines, which would establish a framework for capacity development, has remained under discussion in the Russian parliament since 1999; the draft was approved in 2006 in the first reading but has failed to progress further. Gazprom suggested that third parties should be required to contribute finance towards new and incremental construction with their expenses to be compensated through transportation tariffs, ${ }^{48}$ although it was difficult to see how such a solution might be workable given that tariffs charged to third parties were already regulated (see Section 3). ${ }^{49}$ However, should new legislation require both Gazprom and third parties to be charged regulated tariffs which would more accurately reflect their load factors, this might pave the way for adequate resolution of the issue of new and incremental capacity development.

\footnotetext{
${ }^{44}$ For Sakhalin 2 expansion to be commercially viable, it would need to use gas from Sakhalin 1 in addition to Sakhalin 2 gas; therefore, the government's position on bringing the Sakhalin 2 and Sakhalin 1 parties to agreement would be crucial. Such agreement is made more likely because of EU and US sanctions, forbidding the Sakhalin 1 and 2 companies to engage in new high-tech Russian projects, including in the gas sector.

${ }^{45}$ Nonetheless, even if the sanctions might not have a direct impact on Sakhalin 2 expansion, they might have an indirect impact as potential buyers - specifically Japanese and Korean - might be reluctant to conclude new contracts for Russian gas as long as the sanctions remain in place. Notably Gazprom has put this expansion plan back to 2021 in its latest pronouncement.

${ }^{46}$ Gazprom, 'Viktor Timoshilov: complex approach is necessary while planning and implementing major gas projects in the Far East', press release, 23 September 2014, http://www.gazprom.ru/press/news/2014/september/article201829/

${ }^{47}$ Seliverstov and Gudkov (2012), p. 412.

48 'Gazprom has summed up its preliminary 2014 results, Gazprom, N 1-2, January-February 2005.

${ }^{49}$ Stern (2005), p. 37.
} 

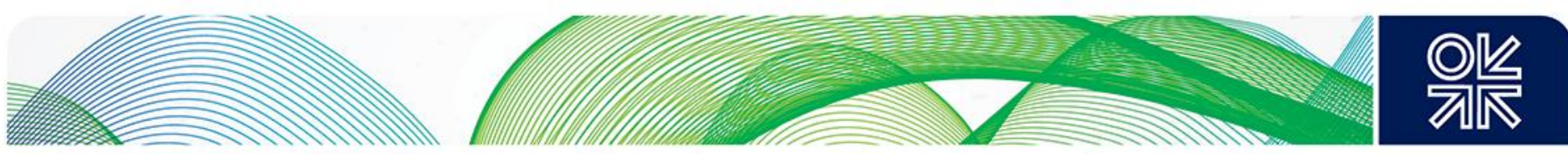

As long as no adequate framework defining the source and the mechanism of financing new and incremental capacity is implemented, it is difficult to expect Gazprom to finance and build such capacity to accommodate third party gas (particularly given the lack of profitability in the transmission sector at the existing level of transmission tariffs). Likewise, it is difficult to expect third parties to finance and build UGS system capacity since, as Seliverstov and Gudkov argue, the principle of indivisibility of the UGS system presupposes that all these networks, plus expansions 'shall be owned by Gazprom, irrespective of who financed their creation or expansion' ${ }^{50}$ Furthermore, according to the same principle, should the networks, built by third parties outside the UGS system be connected to it afterwards, they 'shall be centrally managed by Gazprom'. ${ }^{51}$

As third party usage of the UGS and non-UGS systems is set to increase, the issue of how incremental and new pipeline construction should be funded is becoming increasingly important. Additional urgency to establish an adequate regulatory framework for new pipeline construction and utilization has been created by the EGP (see Section 1.2). Development of, and rules of access to, new transport infrastructure is the key to EGP success.

\footnotetext{
${ }^{50}$ Seliverstov and Gudkov (2012), p. 412.

51 lbid, p. 412.
} 

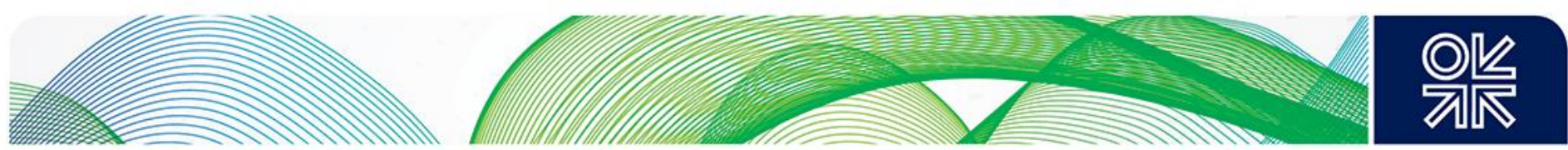

\section{Third-Party Access to UGS and non-UGS Systems: access and allocation rules}

Under the Law on Gas Supply the owners of all gas supply systems (i.e. both UGS and non-UGS) are obliged to provide non-discriminatory third-party access (TPA) to available (spare) capacity in these systems to any party operating on Russian territory, ${ }^{52}$ in line with the rules set by the Russian government (Art. 27). ${ }^{53}$ Notably, parties requesting access for transportation of associated gas, are prioritized (Art. 27). ${ }^{54}$ However, the government has only established rules of access to the UGS system (Resolution No 858, see Section 2.1) - of limited scope and insufficient detail - but not to nonUGS systems. Thus only a general framework (in the form of the Law on Gas Supply) in respect of non-discriminatory access to non-UGS systems currently exists. ${ }^{55}$

The implementation and enforceability of a general framework is problematic due to the absence of definitions and mechanisms. Although the Law on Gas Supply obliges the owners of both UGS and non-UGS systems to provide non-discriminatory access to spare capacity, it does not define 'spare capacity'; 56 it also does not contain access and capacity allocation mechanisms. This makes it extremely difficult to use the Law on Gas Supply for enforcing non-discriminatory access to non-UGS systems.

The Law on Competition complements the general framework, provided by the Law on Gas Supply, by establishing a set of rules aimed at ensuring a competitive environment in all sectors of the economy. ${ }^{57}$ The Law on Competition's articles, which could be used by the Federal Anti-Monopoly Service (FAS) as a basis for an infringement procedure against a gas market player include inter alia: "Establishment of monopolistically high price" (Art. 6), "Establishment of monopolistically low price" (Art. 7), "Prohibition of abuse of a dominant position" (Art. 10), "Prohibition of agreements limiting competition" (Art. 11), "Prohibition of unfair competition" (Art. 14). Notably, all the infringement procedures, opened by the FAS in respect of access to non-UGS systems, were based on the Law on Competition.

There has been growing understanding on the part of the Russian government that existing legal/regulatory frameworks regulating access to UGS and non-UGS systems as well as transportation tariffs are not fully adequate for the changing Russian gas market and constitute an obstacle to its development, while also negatively impacting the economy as a whole. The issue has become increasingly important as several new UGS (e.g. the Russian Southern Corridor pipeline) and non-UGS (Trans-Sakhalin, SKV and Power of Siberia) pipelines either exist or are under development.

In June 2014, the Presidential Energy Commission, headed by President Putin, mandated the Russian government to develop a new concept of Russian gas market development which, inter alia, would ensure non-discriminatory access to both existing and new UGS and non-UGS systems. (In

\footnotetext{
52 "Any organisations conducting activity", see the Law on Gas Supply.

${ }^{53}$ The wording 'any party' suggests that not only producers but also traders can request access.

${ }^{54}$ Priority access for third party associated gas was introduced via an amendment made in late 2012.

55 The 2014 FAS investigation into (Gazprom-controlled) Sakhalin Energy's refusal to provide access to the Trans-Sakhalin pipeline was based on alleged violation of the Russian Law on Competition.

${ }^{56}$ Note that a definition of 'spare capacity' in the UGS system is provided by Resolution No 858, discussed in Section 2.1; definitions of 'spare capacity' are also provided by draft Resolutions on non-discriminatory access to high pressure gas pipelines, discussed in Section 2.3.

${ }^{57}$ Federal Law "On Competition in the Russian Federation" No 135- Ф3, 26 July 2006 (with amendments up to 4 June 2014 No 143-Ф3), hereafter "The Law on Competition". Note that the Law was amended on 21 July 2014 (No 265-Ф3) but at the time of writing the amended version has not entered into force.
} 

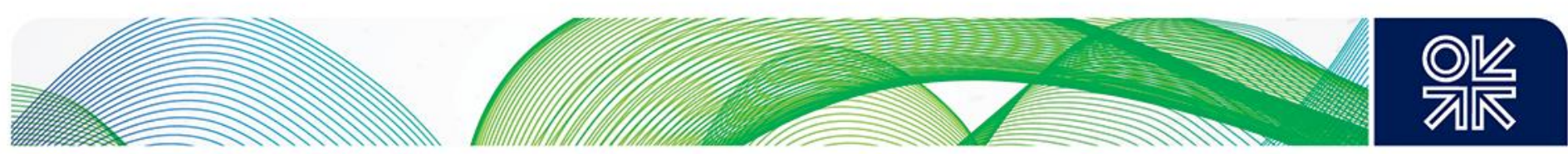

particular, the EGP implementation requires development of detailed rules governing access to nonUGS systems.)

Speaking at the meeting of the Commission, Putin made several suggestions in respect of the future transportation regime: 58

- establishment of common principles for calculating tariffs charged for gas transportation through the UGS system both for Gazprom and third parties, thus encouraging a transition from wholesale gas price regulation to transport tariff regulation;

- elimination of subsidization of gas transportation under export contracts by domestic consumers (thus implying non-inclusion of export pipeline construction cost in the domestic transportation tariff);

- development of a legal/regulatory framework ensuring non-discriminatory access for all suppliers holding long-term contracts, prioritizing transportation of gas traded at the exchange.

The government was expected to present its suggestions to the Commission for discussion and/or approval in late 2014. The aim of the new framework is to create a level playing field for Gazprom and third parties in the domestic market, while also ensuring that Russia's competitive position in export markets (European and Asian) is maintained.

\subsection{The rules of TPA to the UGS system: Resolution No 858}

As the sole owner of the UGS system, Gazprom is obliged to manage and undertake dispatch control of all the components of the UGS system (including the GTS) as well as any other facilities connected to it, and thus has an exclusive right to transport third party gas through the UGS system.

The rules of TPA to the UGS system were laid down in the 1997 Resolution No $858,{ }^{59}$ which mandated that access must be provided subject to the following requirements:

- existence of transportation agreements (contracts) concluded between a (non-Gazprom) third party and Gazprom (or Gazprom's transmission operators at Gazprom's request); 60

- availability of spare capacity in the system from the entry to exit point during the period proposed by a third party,

- 'spare capacity' is defined as technically possible capacity to accept and transport gas excluding volumes transported for Gazprom and for third parties under contracts in force at a certain point in time, as well as volumes transported by Gazprom in line with presidential and governmental orders on compulsory supplies;

- compliance of third party gas with quality standards and technical specifications;

- availability of intake/offtake pipeline connections with metering and quality control equipment, by the proposed start date of transportation.

\footnotetext{
58 'The meeting of the Presidential Commission on strategy for energy sector development and environmental security' (transcript, in Russian), 4 June 2014.

${ }^{59}$ Resolution No 858, On ensuring access of third parties to the Gazprom gas transportation system, 14 July 1997 (with amendments from 20 November 1999 No 1275, 02 November 2000 No 843, 03 May 2001 No 334, 16 April 2012 № 323, 19 June 2014 No 566), http://base.consultant.ru/cons/cgi/online.cgi?req=doc;base=LAW; $n=164592$. As Stern notes, Russia introduced rights of TPA to the UGS system before similar rights were introduced by the European Union's First Gas Directive, see Stern (2005), p. 179

${ }^{60}$ Notably, third parties (gas owners) conclude 'ship-or-pay' transportation contracts with Gazprom, see Eastern Gas Programme (2007).
} 

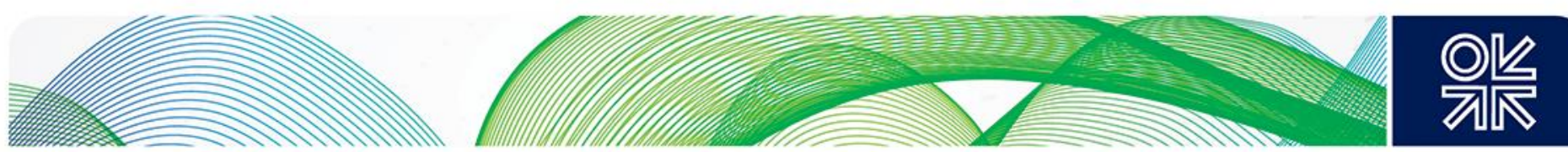

On their part, third parties must submit to Gazprom a request for capacity which inter alia must contain the following: the sources of gas (Art. 6.2), the intended supply period (Art. 6.3), supply volumes (Art. 6.4), the points of intake and offtake (Art. 6.7 and 6.8), documents confirming either ownership of gas or existence of contractual obligations to buy (sell) gas (Art. 6.10). ${ }^{61}$

The time schedule for submitting the access requests is as follows:

- for short term (capacity) contracts (less than or equal to one year): not later than one month before and not earlier than three months before the intended date of delivery;

- for medium-term contracts (more than one year and less than or equal to five years): not later than three months in advance and not earlier than one year before the start of intended year of delivery;

- for long-term contracts (more than five years): not later than six months in advance and not earlier than three years before the start of intended year of delivery (Art. 8).

Should there be insufficient spare capacity to grant all the third parties' requests, the capacity allocation mechanism dictates that access will be allocated in proportion to volumes requested in the following order (Art. 10):

- suppliers covering the residential sector's communal and social needs, and suppliers of associated gas;

- organizations which buy and sell gas at the exchange;

- suppliers with longer term contracts.

There is no single procedure for dealing with the remaining third party requests. The Resolution stipulates that such requests are to be granted either in line with the competition law (which, as noted earlier, only provides a general framework), or proportionally to the volumes declared for transportation (i.e. on a pro-rata basis), or on a tender basis, the rules for which are defined by government (Art. 10). This suggests that Gazprom retains a certain degree of discretion (and hence room for potential discrimination) as to how such requests are handled.

Although Resolution No 858 was an important step in establishing the rights of access for third parties to the UGS system, its scope and level of detail remained limited. Here we concur with Seliverstov and Gudkov who singled out the Resolution's limitations of scope, stressing that that the Resolution does not:

- regulate access to non-UGS systems;

- govern relations between the UGS system owner (i.e. Gazprom) and its subsidiaries (but only UGS system owner relations with third parties);

- govern access to storage and LNG infrastructure;

- contain anti-hoarding mechanisms;

\footnotetext{
${ }^{61}$ Art. 6.10 in the current version of Resolution 858 obliges a third party to present documents confirming ownership of gas or existence of contractual obligations to buy (sell) gas (so it is not clear whether contractual obligations to buy/sell gas serve as confirmation of ownership of gas or the existence of a buyer for that gas). The wording of Art. 6.10 in the previous version of Resolution 858 obliges a third party to present documents confirming ownership of gas. The draft Resolution stipulates that a party requesting capacity is obliged to provide documents confirming ownership of gas and copies of contracts to buy/sell (deliver) gas for state, municipal and communal organisations as well as for the residential sector. Interestingly the draft Resolution allows an application for capacity if a third party does not have ownership rights over gas at the moment of application but can prove that it will have such ownership rights in the future.
} 

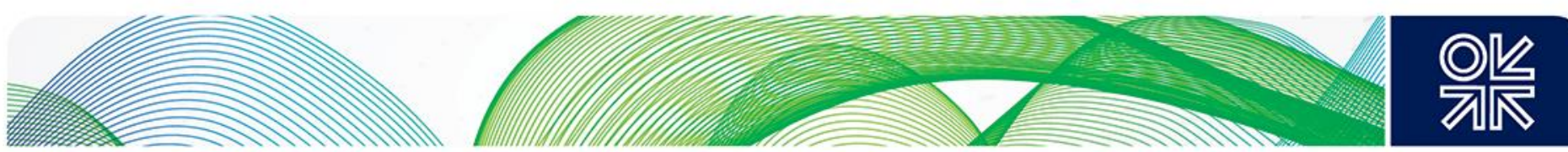

- regulate connections to the UGS system. ${ }^{62}$

Both Gazprom and third parties have often been critical about the implementation of Resolution 858. Third parties have complained about their rights of access to the UGS system being violated, particularly noting the lack of clarity of capacity allocation rules, the lack of cost-reflectivity of tariffs, and sub-optimality of transportation routes chosen by Gazprom for third party gas (see Section 3). Gazprom, on its part, has periodically complained that third parties were using the network without contributing towards its development while also often being "out of balance, leaving gas in the network which acted as a free storage service". 63

However, given that in 2013 third parties accounted for $27 \%$ of total Russian gas production, the share of their gas transported though the GTS has remained much below the level it would have reached had independents been able to gain proportionate access to the UGS system. It is worth recalling that the 1992 Presidential Decree No 1333 obliged Gazprom to provide any gas producer with access to the UGS system proportional to its domestic production, provided that a single mechanism for price regulation is observed. ${ }^{64}$ But to date, the latter condition has not been fulfilled as Gazprom is obliged to sell gas at regulated prices, whereas third parties are free to sell their gas at unregulated prices (see Section 3.3). ${ }^{65}$

Yet despite the limitations of Resolution No 858, and at odds with 'well-publicized instances of Gazprom reluctance to provide gas transportation services', the volume and the share of third party gas transported by Gazprom through the UGS system's GTS has been steadily increasing. In 2013 Gazprom transported $111.4 \mathrm{bcm}$ of third party gas, or $16.9 \%$ of GTS throughput (Table 2). ${ }^{66}$

\footnotetext{
62 Seliverstov and Gudkov (2012), pp. 401-402.

${ }^{63}$ Stern (2005), p. 182.

${ }^{64}$ Presidential Decree No 1333, 'On Gazprom transformation from the state gas concern to the Russian joint stock company, 5 November 1992.

${ }^{65}$ Given that regulated prices have remained above unregulated prices during 2012-14, with Gazprom prevented by law from selling its gas at a discount, Gazprom has lost significant market share to third parties, particularly to Novatek and Rosneft. In 2014 the government considered granting Gazprom a right to sell gas at a 10\% discount to regulated price but to date no decision has been made.

${ }^{66}$ Major third-party users of the GTS were Novatek and NGK Itera which accounted for approximately $40.4 \%$ and $21.6 \%$ of supplies by independent suppliers, respectively, see Gazprom, Preliminary Bond Prospectus, 12 July 2013, p. 137.
} 

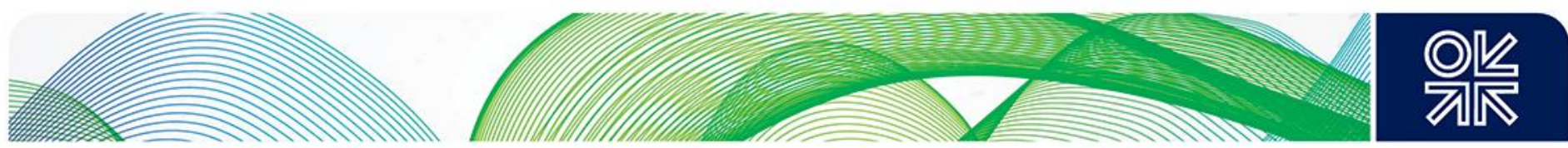

Table 2: Gazprom's Transport of its Own and Third Party Gas, 2008-13

\begin{tabular}{|l|l|l|l|l|l|l|}
\hline Year & $\begin{array}{l}\text { Gas } \\
\text { transported } \\
\text { through the } \\
\text { GTS by } \\
\text { Gazprom and } \\
\text { third parties } \\
\text { (bcm) }\end{array}$ & $\begin{array}{l}\text { Volumes } \\
\text { supplied to } \\
\text { export } \\
\text { markets, } \\
\text { (bcm) }\end{array}$ & $\begin{array}{l}\text { Volumes } \\
\text { supplied to } \\
\text { the } \\
\text { domestic } \\
\text { market by } \\
\text { Gazprom } \\
\text { and third } \\
\text { parties } \\
\text { (bcm) }\end{array}$ & $\begin{array}{l}\text { Volume of third } \\
\text { party gas } \\
\text { transported, } \\
\text { (bcm) }\end{array}$ & $\begin{array}{l}\text { Russian gas } \\
\text { production } \\
\text { by third } \\
\text { parties (bcm) }\end{array}$ & $\begin{array}{l}\text { Transportation of } \\
\text { Third Party Gas as } \\
\% \text { of total UGS } \\
\text { system throughput } \\
(\%)\end{array}$ \\
\hline 2008 & 714.3 & 251.1 & 352.8 & 111.2 & 113.9 & \\
\hline 2009 & 589.7 & 195.6 & 335.6 & 60 & 120.9 & 15.6 \\
\hline 2010 & 661.2 & 209.3 & 354.9 & 72.6 & 141.7 & 11.0 \\
\hline 2011 & 683.2 & 217.7 & 365.6 & 81.5 & 155.8 & 11.9 \\
\hline 2012 & 666.2 & 209.3 & 362.3 & 95.8 & 169 & 14.4 \\
\hline 2013 & 659.4 & 220.2 & 354.6 & 111.4 & 180.6 & 16.9 \\
\hline
\end{tabular}

Source: Gazprom Annual Report 2013 (p. 48), Gazprom in Figures 2009-2013: factbook (p. 48), Gazprom Annual Report 2012 (p. 55), Gazprom's Annual Report 2009 (p. 45), Gazprom Annual Report 2008 (p. 37). Gazprom, Preliminary Bond Prospectus 2013.

The Gas Exchange, which was first established in 2006 but failed to develop and eventually stopped trading in 2008, was re-established in 2014 (in line with the Protocol of the Presidential Energy Commission meeting in July 2014). The gas trading platform was re-established on the St Petersburg Mercantile Exchange (SPIMEX) where both Gazprom and third parties could trade gas at unregulated prices; $10 \%$ of total supplies for the domestic market $(35 \mathrm{bcm})$ are expected to be traded annually as of 2015; the first trade took place on the October 24th $2014 .{ }^{67}$ Exchange trading is expected to discover a 'market price' for gas on the Russian domestic market, based on supply and demand. ${ }^{68}$ The government wants to establish trading for month, week and day ahead, starting in 2015, thus providing spot prices for the corresponding period; off-exchange transactions will also be registered at the exchange thus facilitating development of additional price indices.

Since the late 2000s, as a result of both government action and market forces, increased competition has developed between Gazprom and third party producers in the Russian domestic market, with third party gas becoming increasingly competitive not only in premium but also regulated sectors (Section 3.3). Renewed efforts have been made to establish a more efficient TPA regime to make it easier for third party gas to secure capacity in the UGS system and realize its competitive potential. In 2006 the FAS proposed replacing Resolution No 858 with a new act, which would make TPA more efficient; this and multiple other drafts have been prepared since 2006 but have not been adopted (see Section 2.3 for overview and analysis of April 2012, July 2014 and December 2014 drafts). ${ }^{69}$

\footnotetext{
67 FAS, 'The 'Gas' command has been given to all', 24 October 2014, http://www.fas.gov.ru/fas-news/fasnews_35974.html?curPos=340. In late January 2015, Gazprom withdrew temporarily from exchange trading citing unresolved taxation issues due to which its continuing participation could result in an additional tax burden, see 'Gazprom suspends participation in trading platform over tax issue', Interfax, 27 January 2015 and FAS, 'FAS will determine the measures against Gazprom for non-participation in gas exchange trading', 3 March 2015 http://fas.gov.ru/fas-in-press/fas-in-press_40319.html

${ }^{68}$ FAS, 'Anatoly Golomolzin for unified tariff-setting on gas transportation', 24 October 2014 http://www.fas.gov.ru/fas-news/fasnews_35976.html

${ }^{69}$ lbid, p. 402.
} 

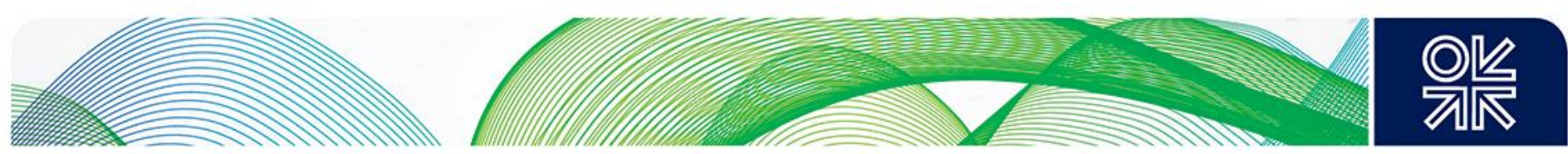

In parallel with trying to advance new legislation, the FAS launched several investigations into alleged Gazprom discrimination against third parties: 28 out of 212 antimonopoly cases in the gas sector considered in 2008-11 related to TPA issues. ${ }^{70}$ Some of these cases went in favour of third parties with Gazprom found guilty of violating competition law (e.g. in 2010, by failing to consider requests made by Gaz-Energo-Aliance for access to the UGS system; in 2012, by refusing access to the UGS system to the Real-Gaz company despite having been able to transport its gas as requested). Some went in favour of Gazprom e.g. in 2010, when Gazprom was found not guilty of violating competition law for refusing access to the UGS system to Rosneft on technical grounds. ${ }^{71}$

Overall the FAS has become increasingly vocal in stating that TPA has remained problematic, and the conflict of interest arising from Gazprom being the owner of the UGS system and the major gas producer/shipper has led in some instances to access refusals. ${ }^{72} \mathrm{~A}$ growing number of cases alleging Gazprom's discriminatory behaviour, which were brought to its attention, suggested that a more comprehensive regulatory framework, governing access to the UGS than the one provided by Resolution No 858 might be necessary.

\subsection{Non-UGS Systems: TPA to the Eastern Gas Programme pipelines (case studies)}

Imperfect as Resolution No 858 is in respect of TPA to the UGS system, no framework with a comparable level of detail exists in respect of TPA to non-UGS systems. There is an urgent need to fill this regulatory void as an increasing number of major non-UGS systems have been (and are being) built, including the Trans-Sakhalin pipeline, the Sakhalin-Khabarovsk-Vladivostok (SKV) pipeline and the Power of Siberia pipeline.

These systems were (or are planned to be) built with a view to forming the complex of technologically, organizationally and economically connected and centrally managed production, transportation, storage and supply objects which is independent from the UGS system. ${ }^{73}$ Therefore in legal terms, these pipelines appear to fall under the category of regional supply systems (until and unless they are connected to the UGS system thus becoming part thereof).

For example, the Trans-Sakhalin pipeline was built to connect the Sakhalin production facilities with the Prigorodnoye LNG plant. The SKV pipeline, itself an expansion of the Sakhalin-Khabarovsk pipeline, was built with a view to connecting Sakhalin production facilities with domestic consumption centres. The Power of Siberia pipeline would serve a similar purpose as it is envisaged to connect Gazprom's production fields in east Siberia with consumption centres in China, while also supplying the Russian domestic market.

It would be more difficult to classify the Altai pipeline as a regional supply system as it could be argued that its construction would constitute an expansion of the existing UGS system rather than a separate system, as it would connect producing fields in west Siberia which are already part of the UGS system. In turn, this would suggest that the issues of access to the Altai pipeline would be subject to the detailed legal/regulatory framework provided by Resolution No 858, rather than to the general framework provided by the Law on Gas Supply and the Law on Competition (as would be the case with non-UGS systems).

\footnotetext{
${ }^{70}$ Smirnova (2012).

${ }^{71}$ Smirnova (2012).

72 Smirnova (2012).

73 The Law on Gas Supply.
} 

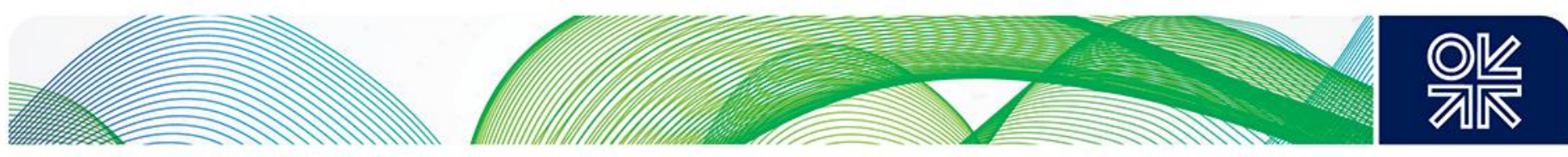

Importantly, non-Gazprom producers operating in the region, specifically Rosneft in Sakhalin 1 and 3, have demanded access to the Trans-Sakhalin and SKV pipelines, as well as the (yet to be built) Power of Siberia pipeline, both for domestic and export sales. Third party determination to gain access to domestic pipeline capacity, allowing them not only to supply gas domestically, but also bring it to their planned LNG plants for export, strengthened following the abolition of Gazprom's LNG export monopoly in 2013. Third parties have also expressed interest in gaining access to pipeline export capacity despite the continuing existence of the Gazprom monopoly.

\subsubsection{Power of Siberia Pipeline}

The Power of Siberia pipeline is planned to connect the Irkutsk and Yakutia production centres in eastern Siberia with north east China at Blagoveshchensk on the Russian-Chinese border. ${ }^{74}$ It would initially run from the Chayanda field in Yakutia, with a possibility of connecting with the Kovykta field near Irkutsk at a later stage. Gazprom Transgaz Tomsk started construction in September 2014 with a view to the pipeline becoming operational in late $2017^{75}$ though the date has since been changed to $2020 ;{ }^{76}$ the pipeline's planned capacity is $61 \mathrm{bcm} /$ year. Its construction is underpinned by the Gazprom-CNPC contract, signed in May 2014. The pipeline would transport $38 \mathrm{bcm} / y e a r$ of gas to China with the remainder of the capacity to be used for domestic consumption.

Other parties have already expressed interest in the Power of Siberia pipeline capacity. In particular, Rosneft wants to export associated gas from its east Siberian fields to China (despite not having a legal right to do so). According to Gazprom's deputy CEO, Alexander Medvedev, the Gazprom-CNPC contract calls for the pipeline to be completely filled with Gazprom's gas, and granting third party access would reduce profitability at the Gazprom fields that have been designated as the resource base for the pipeline. This suggests that Gazprom would not have invested in the project unless it could use only its own gas for the supply contract and that it views this as an integrated project (i.e. production and transportation) rather than simply a pipeline investment. ${ }^{77}$

As Gazprom wants to ensure that it will be the sole user of the pipeline for supply to domestic and export markets, it declined the Russian government's offer to provide it with extra capital for pipeline construction ( $\$ 25$ billion) as acceptance of this offer could have been used by the government as justification for allowing non-discriminatory access to the pipeline. ${ }^{78}$ Gazprom's refusal of governmental support was made at a time when it believed it could secure Chinese funding for pipeline construction (either as an advance payment for gas or as a loan), however no such agreement has been reached to date. ${ }^{79}$

\footnotetext{
${ }^{74}$ Initially the possibility of the pipeline going further east to Vladivostok was considered but appears to have been abandoned in 2014, when Gazprom signalled it might shelve its Vladivostok LNG plant, see 'Gazprom considers shelving Vladivostok LNG project', Financial Times, 10 October 2014.

${ }^{75}$ Gazprom, 'The Power of Siberia pipeline construction has started', press release, 1 September 2014,

http://www.gazprom.ru/press/news/2014/september/article199948/?from=banner

76 'The start of gas transportation through the Power of Siberia pipeline has been delayed by two years', Vzgliad, 30 September 2014.

77 'Issue of Chinese advance for power of Siberia up in air', 23 September 2014, Interfax CIS Oil \& Gas Weekly, 23 September 2014.

78 'Ransom for monopoly', Kommersant, 5 June 2014.

79 'The Chinese refused Gazprom the money to build the Power of Siberia pipeline', Vedomosti, 24 September 2014, 'Issue of Chinese advance for power of Siberia up in air', Interfax CIS Oil \& Gas Weekly, 23 September 2014.
} 

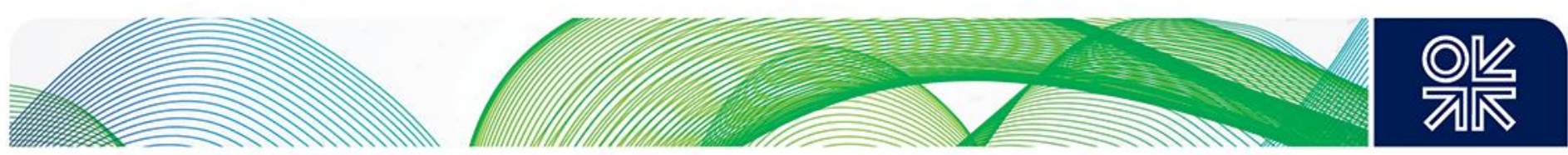

As noted above, the Law on Gas Supply and the Law on Competition provide only a general framework governing construction of, and access to, new non-UGS system pipeline capacity. In June 2014, the Presidential Commission on Energy mandated the government to develop suggestions for non-discriminatory access to the Power of Siberia pipeline. ${ }^{80}$ Reportedly, several proposals have been made including a suggestion to oblige Gazprom to buy third party gas either at 'cost plus' or 'export net back' prices and a suggestion to create a consortium, which would include Gazprom and third parties, for financing construction. ${ }^{81}$ Other possibilities included a suggestion that Gazprom itself finance pipeline construction but any expansions necessary for accommodating third party gas would have to be financed through an investment tariff - this however seems problematic as third party tariffs are already regulated. It is believed that the Gazprom-CNPC supply contract is commercially sound but by no means lucrative for Gazprom, ${ }^{82}$ therefore any solution on access should be such as not to significantly worsen the project economics. To date, no decision has been reached by the government. However, the process of decision making, including the aforementioned suggestions, provide an indication as to how future regulation of non-UGS system capacity might develop.

\subsubsection{The Altai Pipeline 83}

The Altai pipeline, which is planned to connect western Siberia (and potentially Yamal Peninsula) production centres with north-west China, has long been Gazprom's preferred transportation route for supplies to China. This pipeline would allow Gazprom to optimize its west Siberian resource base and provide an arbitrage opportunity between sales to Europe and Asia. ${ }^{84}$ Following the conclusion of the contract for gas through the Power of Siberia pipeline, Gazprom and CNPC signed a memorandum of understanding in respect of Russian gas exports to China via the Altai pipeline. Officials from both companies have stated that they expect a contract to be signed around the middle of 2015 and deliveries to start in the early to mid 2020s. ${ }^{85}$ As noted earlier, should the Altai pipeline be considered as part of the UGS system, third party requests for access would be dealt with in line with Resolution No 858 (see Section 2.1). Should the Altai pipeline be considered a non-UGS system, it would only be regulated by a general framework provided by the Law on Gas Supply and the Law on Competition governing access to non-UGS systems, with a more detailed regulation yet to be developed by the government.

\footnotetext{
80 'The meeting of Presidential Commission on strategy for energy sector development and environmental security' (transcript, in Russian), 4 June 2014.

81 'Minenergo has not found access to the Power of Siberia pipeline', Vedomosti, 11 September 2014.

82 Henderson (2014).

83 'Altai' (Gazprom project description), http://www.gazprom.ru/about/production/projects/pipelines/altai/

${ }^{84}$ Henderson (2014).

85 Ibid. In fact Gazprom officials suggest that if the contract is signed in 2015, deliveries could start before 2020 because a great deal of the preparatory work has been completed, and much of the route is already established (although a new line would need to be laid).
} 

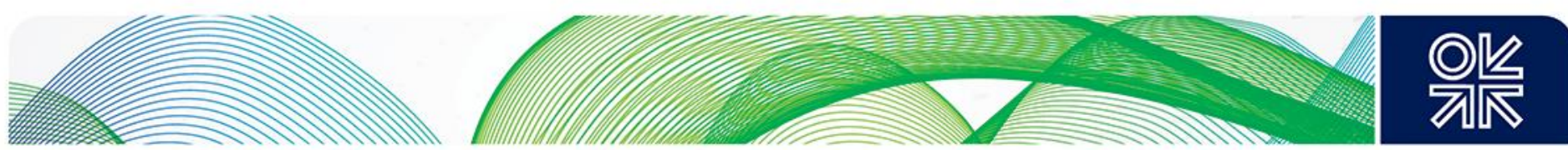

\subsubsection{The Trans-Sakhalin Pipeline ${ }^{86}$}

The Trans-Sakhalin pipeline system is part of the Sakhalin 2 project, carried out under the 1994 PSA. ${ }^{87}$ The pipeline consists of $300 \mathrm{~km}$ of offshore and $1,600 \mathrm{~km}$ of onshore gas (and oil) pipelines. It started operation in 2008 transporting gas (and oil) from two offshore fields (Piltun-Astokhskoye and Lunskoye) to the Prigorodnoye LNG plant. The capacity of the pipeline is $18.6 \mathrm{bcm} / \mathrm{year}$ with possibilities for expansion $(16.4 \mathrm{bcm}$ was transported in 2013), and is operated by Gazprom Transgas Tomsk. 88

The Trans-Sakhalin pipeline differs from other non-UGS regional supply systems in one important respect, namely that access to it is governed not only by the Law on Gas Supplies and the Law on Competition but also by the PSA, which stipulates the rules of access to various project facilities, including pipelines.

In respect of hydrocarbons (being sold by Sakhalin Energy or its affiliated companies) in connection with the Sakhalin 2 project, either in the domestic or export markets, the PSA prohibits: 89

- mandatory usage of transportation, processing, storage, export facilities for whatever purposes (Art. 1.c);

- obligations to sell or export hydrocarbons with participation or via any defined state, quasi-state, or commercial organizations or structures, or directed at detrimental effect or against sales or exports of these hydrocarbons by Sakhalin Energy or its affiliated organizations either not via these organizations or without their participation (Art. 1.e);

In respect of hydrocarbon production, transportation, preparation, processing, storage and export facilities built or operated (used) by Sakhalin 2 or its affiliated companies), the PSA also prohibits:

- mandatory defined shareholding participation (Art. 4.a);

- mandatory establishment of a right of any organization, which is not a party to the PSA, to have access to the aforementioned facilities or their usage (Art. 4.b);

- fixed tariffs, maximum allowed tariffs, defined limits of tariff changes or any other means of regulation or limitations on the tariffs in respect of payments, which can be charged by Sakhalin Energy or its affiliated organizations for usage of the aforementioned facilities by third parties (Art. 4.c).

Importantly, the PSA also contains specific provisions for the possibility of capacity expansion. Specifically, it says that 'certain objects, created as part of the project, may have spare capacity (or their modernisation or reconstruction may result in spare capacity)' (Art. 19.e). ${ }^{90}$ Sakhalin Energy 'has a right to conclude agreements with third parties (independently of whether or not they are parties to the PSA $)^{91}$ to use such spare capacities for servicing other fields which do not constitute part of

\footnotetext{
86 'Operating the trans-Sakhalin pipeline system', Pipelines International, March 2013,

http://pipelinesinternational.com/news/operating_the_trans-sakhalin_pipeline_system/080362/

${ }^{87}$ The Agreement on the development of Piltun-Astokhsky and Lunsky oil and gas fields on the basis of production sharing (thereafter "The Sakhalin 2 PSA"), June 1994, http://www.ecosakh.ru/?div=59\&id=99

88 'Miller is ready to allow Rosneft access to the Trans-Sakhalin pipeline', 7 August 2014, http://infox.ru, 'No place for Rosneft in the Sakhalin 2 pipeline', Vedomosti, 13 October 2014

89 "The Sakhalin 2 PSA" (Annex E, Addendum 4).

90 "The Sakhalin 2 PSA" (Main text).

${ }^{91}$ The Russian state being Sakhalin Energy's only counter party on the Sakhalin 2 PSA, this wording suggests that such agreements could also be concluded with non-state actors.
} 

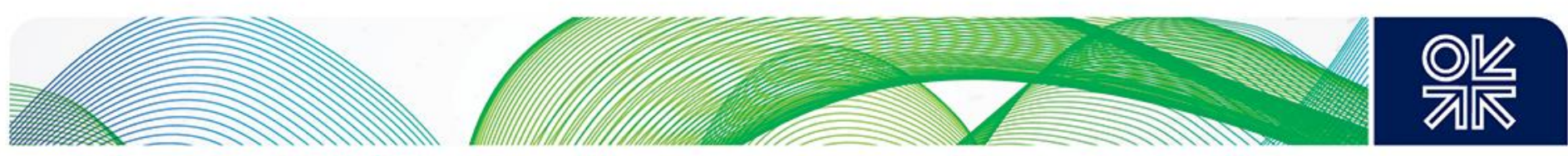

Piltun-Astokhskoye and Lunskoye license areas, provided that such was approved by its monitoring board'. Sakhalin Energy is obliged to 'endeavour to use free capacities taking into account its obligations under the PSA'; costs incurred by Sakhalin Energy to purchase hydrocarbons to enable such capacity usage are to be compensated as envisaged by the PSA (Art. 14). ${ }^{92}$ This suggests that Sakhalin Energy has a right to provide non-discriminatory access to the Trans-Sakhalin pipeline under the PSA (and the monitoring board approval is necessary to realise this right), in contrast to the obligation to provide such access under the Law on Gas Supply, should there be spare capacity in the pipeline.

The PSA also contains important provisions in respect of ownership of various assets, including the project's pipelines. Sakhalin Energy has ownership rights over assets acquired or created (as part of costs incurred by the project). Ownership rights are transferred to the Russian government only after all capital costs, incurred in respect of such assets, have been fully reimbursed (operational costs are to be reimbursed first) (Art. 19.b). ${ }^{93}$ Should the PSA cease to be in force before these costs have been reimbursed, the ownership rights over the assets are transferred to the Russian government but the latter provides Sakhalin Energy with an exclusive right to continue using such assets free of charge. As long as Sakhalin Energy has desire or necessity to use these assets, the Russian government will not inter alia use, rent out, lease or sell these assets, as well as carry out or allow any activity in respect of these assets which would limit an exclusive right of Sakhalin Energy to use these assets or create obstacles to exercising this right (Art. 19.d).

Rosneft has repeatedly sought access rights in the Trans-Sakhalin pipeline (in order to transport 8 bcm/year of gas from Sakhalin 1 to its planned Far East LNG plant starting from 2018-19). However, in 2013 its request was refused by Sakhalin Energy on grounds of lack of spare capacity in the pipeline. ${ }^{94}$ Gazprom's production department director, Vsevolod Cherepanov, was quoted as saying that additional looping and compression stations would be necessary to grant such a request. In April 2014, Rosneft lodged a complaint with the FAS in respect of refusal of access, and filed a corresponding case against Sakhalin Energy in the Sakhalin arbitration court. ${ }^{95}$ In July 2014 President Putin ordered the government to study the possibility of transferring the infrastructure assets of inter alia Sakhalin 1 and Sakhalin 2 PSAs, including the Trans-Sakhalin pipeline, into state ownership with a view to providing non-discriminatory access to all parties concerned. ${ }^{96}$ This initiative appears to have run aground, possibility due to the strict terms of the Sakhalin 2 PSA, whereby even if the state could potentially succeed in getting ownership rights over the pipeline, it might be impossible to allow access to the pipeline to any third party without the agreement of the Sakhalin Energy board.

For a brief period, it seemed that the issue of access would be resolved amicably. In July 2014, Gazprom's CEO Alexei Miller said that Gazprom was not against granting access in principle, provided that the pipeline would continue to be owned by Sakhalin Energy with a procedure to be developed on how to expand the pipeline capacity. ${ }^{97}$ Furthermore, the (then) Sakhalin governor, Andrei Khoroshavin, stated that the Trans-Sakhalin pipeline could be expanded to accommodate

\footnotetext{
92 "The Sakhalin 2 PSA" (Main text).

${ }^{93}$ Given that Sakhalin 2 started up in 2009, it is unlikely that its (more than $\$ 20$ billion) capex and opex have been reimbursed yet. As long as these expenditures have not been reimbursed, it is the Sakhalin Energy board - and not the state - that has the right and responsibility to decide on TPA to the trans-Sakhalin pipeline.

94 'Gazprom refused Rosneft access to the Sakhalin 2 pipeline', 25 December 2013, http://lenta.ru/news/2013/12/25/refuse/

95 'Rosneft and Gazprom are divided by the pipeline', Kommersant, 13 May 2014.

96 'Putin will allow Rosneft in the trans-Sakhalin pipeline', 16 July 2014, http://lenta.ru/news/2014/07/16/pipe/ Also see 'Russia's Rosneft may get access to Sakhalin 2 pipeline', TASS, 16 July 2014, http://en.itar-tass.com/economy/740857

97 'Miller is ready to allow Rosneft access to the trans-Sakhalin pipeline', 7 August 2014, http://www.infox.ru. See also 'Rosneft will get access to the Sakhalin pipeline' Kommersant, 7 August 2014.
} 

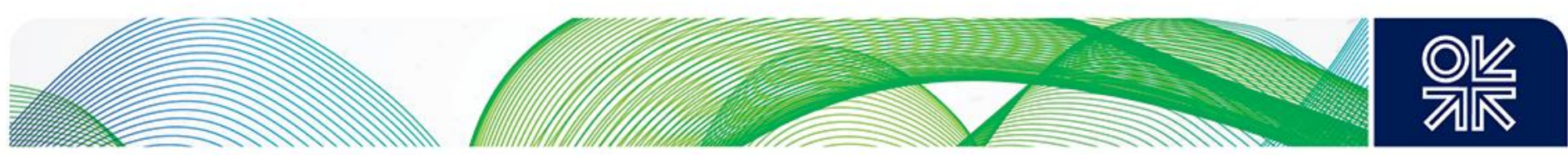

volumes from Sakhalin 1 and the expanded Sakhalin 2.98 However, despite reassuring rhetoric no settlement was reached. The FAS issued a warning to Sakhalin Energy and demanded that it should consider the Rosneft request by the end of July; 99 on August $4^{\text {th }}$ Sakhalin Energy responded by saying that there was no technical possibility of granting the Rosneft request but failed to provide the documents to support its statement. The FAS has subsequently stated that it needed more time to study whether the Rosneft request can be dealt with outside the Sakhalin 2 PSA. It appears that the FAS has come to a positive conclusion, as on August $14^{\text {th }}$ it opened an infringement procedure against Sakhalin Energy on the basis of Art. 10.1.5 ("Prohibition of abuse of a dominant position"): 'economically or technologically unfounded refusal or avoidance from conclusion of a contract with certain buyers (clients) provided there is a possibility of production or supplies of corresponding good'. ${ }^{100}$ In December 2014, the FAS brought administrative charges against Gazprom for its failure to provide necessary information in respect of its refusal of access to the Trans-Sakhalin pipeline; the FAS has also continued to study the Rosneft request and has requested Sakhalin Energy to provide information on contractual volumes supplied under the PSA during 2012-14, as well as forecast volumes up to 2018; information on monthly production and delivery to the Russian domestic market as well as exports. ${ }^{101}$ Meanwhile the court hearings were adjourned until January 2015. In February 2015, the court refused the Rosneft request to be granted access to the trans-Sakhalin pipeline; Rosneft announced it would appeal the decision. ${ }^{102}$

\subsubsection{The Sakhalin-Khabarovsk-Vladivostok (SKV) Pipeline ${ }^{103}$}

The SKV pipeline, operated by Gazprom's subsidiary, Gazprom Transgaz Tomsk, connects the Sakhalin production centre (Sakhalin 3), where both Gazprom and Rosneft are present, with domestic centres of consumption in Khabarovsk and Vladivostok. It would also supply gas to a future Vladivostok LNG plant, which was conceived by Gazprom in 2011 as the means of providing an alternative export option for its east Siberian gas, should the pipeline gas negotiations with China fail. To improve the project's economics, Sakhalin 3 gas was designated as an additional (or potentially alternative) source of supplies to be brought to Vladivostok via the SKV pipeline. The pipeline's current annual capacity is around $6 \mathrm{bcm}$ and it has remained heavily underutilized with $2.2 \mathrm{bcm}$ of gas transported in 2013 (all for domestic consumption); the pipeline's design capacity is $30 \mathrm{bcm} / \mathrm{year}$ (provided that 15 additional compressors are installed). ${ }^{104}$

Following Gazprom's announcement of its intention to shelve its Vladivostok LNG project, which would have been the main SKV destination, it is unlikely that Gazprom will finance the SKV

\footnotetext{
98 'Sakhalin 2 project could pump gas for future Rosneft' LNG plant - Sakhalin governor', Interfax CIS Oil \& Gas Weekly, 22 September 2014, http://www.interfax.com/newsinf.asp?pg=4\&id=538154

${ }^{99}$ Importantly, under Russian law no case analysis appears to be necessary for issuing a FAS warning, with a competitor's complaint being sufficient.

100 'FAS opened an infringement procedure against the Sakhalin 2 operator', Vzgliad, 14 August 2014. The fact that the infringement procedure was opened on the basis of the Law of Competition confirms the correctness of our argument that there is no more specific legal/regulatory framework governing access to non-UGS systems.

${ }^{101}$ FAS, 'FAS has launched an investigation procedure against Gazprom at the Rosneft request', 3 December 2013, available at http://fas.gov.ru/fas-in-press/fas-in-press_39781.html

102 'The court has refused the Rosneft request on access to the Sakhalin Energy pipeline', Vedomosti, 19 February 2015.

103 Gazprom, 'Sakhalin-Khabarovsk-Vladivostok' (Gazprom project description),

http://www.gazprom.ru/about/production/projects/pipelines/shvg/

${ }^{104}$ Henderson and Stern (2014), 'The potential impact on Asian gas markets of Russia's Eastern gas strategy', OIES Energy Comment, February 2014.
} 

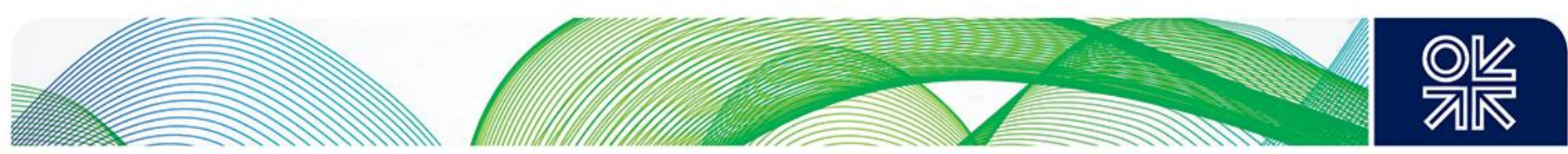

expansion. ${ }^{105}$ Given its low level of utilization by Gazprom, the SKV pipeline could also be used for transporting third party gas and Rosneft has already expressed its interest in doing so. In addition to its plans to build a Far East LNG terminal in Sakhalin, Rosneft also intends to build a massive petrochemical plant (Eastern Oil and Chemical Company, EOCC) at Nakhodka, near Vladivostok. ${ }^{106}$ However, it appears that Rosneft does not have enough gas to support both projects. According to Gazprom's head of Eastern Gas Directorate, Vladimir Timoshilov, Rosneft has asked Gazprom to provide $5.3 \mathrm{bcm} /$ year of gas to be transported via the SKV to Vladivostok and then further to Nakhodka (for which a pipeline extension would have to be built) ${ }^{107}$ while intending to use its own Sakhalin gas for its (planned) Far East LNG plant in Sakhalin via the Trans-Sakhalin pipeline. No solution to this issue has been found yet, and it might not be necessary in the immediate future due to sanctions and delays to some of Rosneft's projects.

\section{Conclusions}

This overview of ongoing disputes in respect of non-discriminatory access to non-UGS systems, developed in eastern Siberia and the Far East under the EGP, suggests that the absence of a detailed legal/regulatory framework establishing specific (and hence enforceable) rules on access and capacity expansion, makes it extremely difficult to ensure non-discriminatory access without direct governmental and/or presidential involvement, as the existing general framework provides significant room for discretion and (mis)interpretation by all market players.

The legal/regulatory framework governing capacity access and capacity expansion in respect of the Trans-Sakhalin pipeline is provided by the general framework constituted by the Law on Gas Supply and the Law on Competition and by the more detailed framework constituted by the Sakhalin 2 PSA, containing specific provisions governing access to, and expansion of, the pipeline. Although the resulting combined framework is more sophisticated than the one provided purely by the above Laws as is the case for e.g. the Power of Siberia pipeline or the SKV pipeline, it still allows significant room for discretion on the part of all actors involved, and hence a final solution is likely to be a result of broad compromise agreement reached at the governmental and/or presidential level. One of the major factors impacting a decision could be the government's view on optimisation of the EGP implementation in Sakhalin in the post-sanctions environment, by establishing a non-discriminatory access regime most appropriate to its vision.

\subsection{Draft Rules on Non-Discriminatory Access to all High-Pressure Pipelines}

There has been a growing understanding within the Russian government that the existing frameworks are not fully adequate for ensuring non-discriminatory access. This is especially the case in respect of access to non-UGS systems, as suggested by our analysis of EGP pipelines (Section 2.2). Several attempts have been made in the 2010s to develop and adopt a new resolution, which would replace the existing Resolution No 858 and would provide a detailed legal/regulatory framework governing access rules to both UGS and non-UGS systems pipeline capacity. In April 2012 the FAS prepared a

\footnotetext{
105 This could change should Vladivostok LNG come back on Gazprom's agenda, but this seems unlikely. Conclusion of the supply contract with China might be the main reason for shelving Vladivostok LNG as well as the potential impact of sanctions in respect of Sakhalin 3, which was the main designated source for Vladivostok LNG.

106 'Rosneft will start preparations for construction of its EOCC petrochemical plant in August', Vedomosti, 22 July 2014 , http://www.vedomosti.ru/companies/news/29266051/rosneft-v-avguste-nachnet-podgotovku-k-stroitelstvu

107 'Gazprom: Rosneft has asked the company for 4.5 bcm of gas for its EOCC', TASS, 23 April 2014, http://itartass.com/ekonomika/1142121
} 

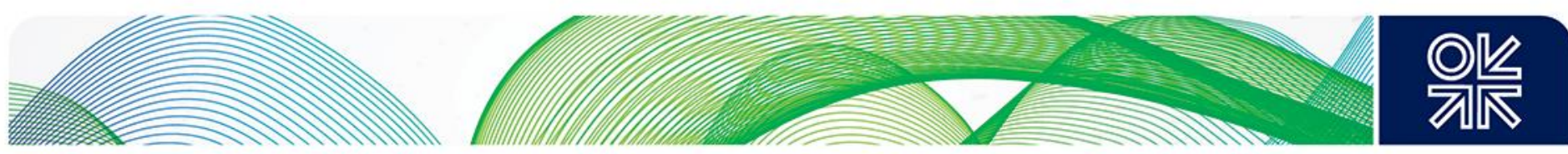

draft resolution ('April 2012 draft Resolution'), 108 which remained a draft and underwent several changes during 2012-14. The process has speeded up following the meeting of the Presidential Energy Commission in June 2014, which mandated the government to develop the concept of a Russian gas market, including the rules of access to UGS and non-UGS systems. ${ }^{109}$ The FAS prepared another draft in July 2014 ('July 2014 draft), ${ }^{110}$ which has been further amended. The most recent publicly available draft was published in December 2014 ('December 2014 draft'). ${ }^{111}$ Section 2.3.1 provides an overview and analysis of these drafts.

\subsubsection{The April 2012 Draft Resolution}

The April 2012 draft Resolution differs from Resolution No 858 in several important respects. Importantly, the scope applied to both UGS and non-UGS systems, and mandated non-discriminatory access to 'spare capacities in high pressure pipelines with the aim of supplying domestic consumers'. Furthermore, it outlined identical rules for Gazprom and for third parties, stipulating that both would have to apply for access to spare capacity in UGS and non-UGS systems on equal terms. Under the April 2012 draft, an entity that possesses a high pressure pipeline (on the basis of ownership or other legal grounds) is obliged to ensure non-discriminatory access to spare capacity in that pipeline. ${ }^{112}$ This approach would entitle all parties access to capacity proportional to their production, ${ }^{113}$ whereas under Resolution No 858 Gazprom effectively has priority access to all UGS capacity, with remaining (spare) capacity offered to third parties.

The April 2012 draft Resolution defines 'spare capacity' as technically possible capacity existing for a certain period of time and on certain sections of the pipeline, except the volumes to be transported:

- for state and municipal purposes;

- for citizens' communal and social needs;

- under transportation contracts concluded before the new Resolution has entered into force (importantly, supplies under extensions of these contracts would have lower priority than new contracts, see below);

- for supplies under Russia's international contracts (i.e. exports).

\footnotetext{
${ }^{108}$ Draft Resolution 'The Rules on non-discriminatory access to high pressure pipelines in the Russian Federation', 11 April 2012 ,

http://economy.gov.ru/wps/wcm/connect/ec61c7004ad85dc2a080abaf3367c32c/pp.pdf?MOD=AJPERES\&CACHEID=ec61c70 04ad85dc2a080abaf3367c32c

109 'The meeting of the Presidential Commission on strategy for energy sector development and environmental security' (transcript, in Russian), 4 June 2014.

${ }^{110}$ Draft Resolution on the rules of non-discriminatory access to services to transport gas through high pressure pipelines and the rules on connection to high pressure pipelines, 3 July 2014,

http://base.consultant.ru/cons/cgi/online.cgi?req=doc;base=PNPA; $=5359$

${ }^{111}$ Draft Resolution on the rules of non-discriminatory access to services to transport gas through high pressure pipelines and the rules on connection to high pressure pipelines,

11 December 2014, http://base.consultant.ru/cons/cgi/online.cgi?req=doc;base=PNPA;n=5359

112 The draft also obliged the entity to ensure pipeline connection.

${ }^{113}$ As envisaged by the Presidential decree No 1333, which envisaged access proportionate to production if a single price setting mechanism for Gazprom and third parties is observed). Importantly, in line with the draft Regulation, a shipper does not have to be a producer.
} 

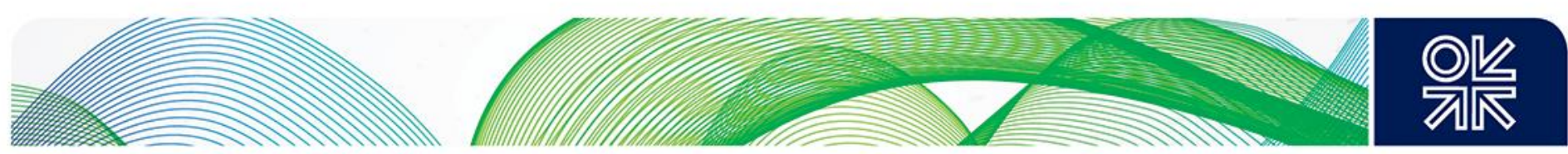

Thus the April 2012 draft Resolution essentially suggested a 'sunset period' - defined by expiry dates of existing (Gazprom and third party) transportation contracts apart from those under which gas is transported for the purposes stated above - after the expiry of which all capacity in the UGS would be allocated to Gazprom and third parties on equal terms.

The April 2012 draft Resolution abolished the category of 'medium-term capacity' (in Resolution No 858) and only distinguished between 'long term' (more than one year) and 'short term' (less than or equal to one year) capacity.

Long-term capacity was to be allocated to each shipper proportional to volumes requested by all shippers (for the first year and beyond), while also taking into account the plans for system development (for the period after the first year). Short-term capacity was to be allocated proportional to requests but only after long-term capacity had been allocated. ${ }^{114}$

Should spare capacity be insufficient for granting all the requests, then capacity was to be allocated in part and proportional to requests in the following order of priority:

- $\quad$ supplies for domestic consumption (including associated gas);

- shippers extending their existing contracts, concluded prior to the new Resolution coming into force (in respect of volumes not higher than actual supplies under these contracts);

- $\quad$ supplies outside Russia (i.e. exports);

- other supplies including for transit across the territories of Customs Union (CU) member states. ${ }^{115}$

Every request for capacity made in line with the rules must be considered and the request must be granted either fully or partially, or on an interruptible basis (provided this is included in the shipper's request) or else refused.

Transportation was to be carried out on the basis of a contract between a transportation owner and a shipper; a contract must contain inter alia the following information: terms and conditions for gas injection, transportation and offtake, volumes for which transportation service is requested, points of entry to and exit from a high-pressure pipeline, payment conditions, and dispute settlement mechanism.

\subsubsection{The July 2014 Draft Resolution}

The July 2014 draft Resolution, suggested by the FAS in the aftermath of the meeting of the June 2014 Presidential Energy Commission, preserved both the scope of the April 2012 draft, covering both UGS and non-UGS systems, and the principle that Gazprom and third parties could apply for, and must be granted, access on equal terms.

At the same time, the July 2014 draft Resolution introduced a number of important changes. For example, its rules would apply to parties seeking access to capacity both for delivering gas for domestic consumption and for exports, whereas the April 2012 draft only stipulated the rules of access to capacity for domestic consumption. This suggests that third parties would be able to request capacity in the Russian domestic pipelines purely for export sales e.g. Rosneft's request for capacity in the Trans-Sakhalin pipeline for deliveries to its Far East LNG plant for onward export sales

\footnotetext{
${ }^{114}$ In line with the draft Resolution, transportation service provided for a period up to 1 year is considered short-term, and for period above 1 year - long-term.

115 Initially the CU membership included Russia, Belarus and Kazakhstan; Armenia and Kyrgyzstan joined as of 1 January 2015.
} 

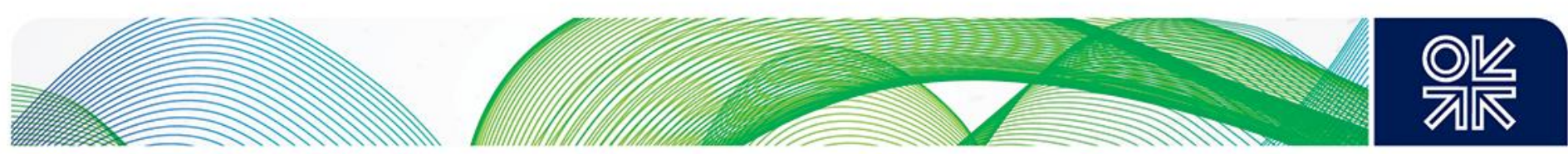

would fall under this category. This provision would become of even greater relevance for third parties should Gazprom's monopoly on pipeline gas exports be abolished in the future.

In contrast with the 2012 draft, which defined the rules for the provision of non-discriminatory access to spare capacities, the July 2014 draft defined the rules for non-discriminatory access to transportation services. Presumably this was made to ensure consistency with the Law on Competition which deals with the category of 'service'.

The July 2014 draft preserved the April 2012 draft definition of 'gas transport company', as an organization, which owns (or otherwise has in its legal possession) a high pressure pipeline and which provides a gas transport service. 'Gas transport service' is defined as a technological process including acceptance of gas into a high pressure pipeline at entry, dispatch and transportation through the pipeline, measurement upon entry and exit of gas from the pipeline, compression and pressure reduction, transfer of gas to consumers at the exit of the pipeline. This expanded the definition provided by the April 2012 draft by clarifying the issue of measurement, as well as adding compression and pressure reduction.

The July 2014 draft defined 'consumer of gas transport service' (i.e. a shipper) as an entity, which owns the gas (or otherwise has it in its legal possession) and meets the resolution's requirements, and which has been granted access to gas transportation, as well as an entity, related to the gas transportation company (including the gas transportation company and gas distribution company) which has been mandated by the owner (legal possessor) of gas. Thus the July 2014 draft stressed that an entity related to the gas transport company, including (that) gas transport company, can itself be a consumer of transport services; this provision was absent from the April 2012 draft. This clarification suggests a declining appetite on the part of the government to break Gazprom into a supply/production and a transportation company, as the July 2014 draft allows Gazprom to apply to itself for capacity access, as is currently the case, albeit under rules identical for all parties.

Should spare capacity be insufficient for the total of requests, the gas transportation company will grant requests proportional to capacity requested, in the following priority order:

- $\quad$ supplies to domestic consumers, including in respect of associated gas;

- supplies of gas acquired at the exchange;

- $\quad$ supplies of gas outside Russia.

This suggests that supply for domestic consumption would be prioritized (irrespective of whether the source is associated gas and whether it has been acquired at the exchange) over exports.

\subsubsection{The December 2014 Draft Resolution}

The July 2014 draft Resolution underwent further changes in a new December 2014 version.

The December 2014 draft Resolution further clarified the definition of 'consumer of gas transport service' defining it as an entity (including a gas transport company), which owns the gas (or has it in its legal possession), meets the requirements set by the draft Resolution and has been granted access to transport service. Unchanged from July 2014, the December 2014 draft wording still allows Gazprom to apply to itself for transport service. However, curiously, both the definition of 'gas transportation company' and 'gas transportation' have disappeared from the December 2014 draft, which might suggest that there is no clear vision and agreement yet within the government in respect of the ownership and operational mandate of gas transportation company or companies that would be providing access to both UGS and non-UGS systems. Yet the December 2014 draft contains a provision allowing a gas transportation company to mandate other companies to provide service in line with a transport contract (Art. 9.a). 

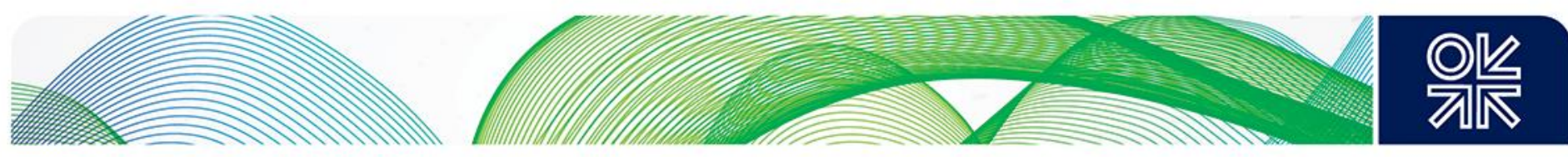

The December 2014 draft Resolution has a clarified definition of 'spare capacity', as 'technically possible capacity for gas transportation, which becomes available during a certain period and on certain sections of pipeline, except the volumes under existing contracts (including international contracts of the Russian Federation) to transport gas during that period of time'. There is a lack of clarity here on the meaning of 'existing' contracts i.e. whether this category refers to contracts that have been concluded before the entry of the new Resolution into force (so called 'legacy' contracts) (as the April 2012 draft suggested); or whether it also refers to all contracts concluded after the new Resolution entered into force but before a request for (spare) capacity has been made. If the former is the case, then the December 2014 draft would safeguard all Gazprom's and third parties' existing export and domestic contracts (irrespective of consumer category) until their expiry, but not new export or domestic contracts (irrespective of consumer category). If the latter is the case, then the December 2014 draft would safeguard all Gazprom's and third parties' existing export and domestic contracts (irrespective of consumer category) until their expiry, as well as new export or domestic contracts (irrespective of consumer category) concluded between the Resolution's entry into force and the time when a request for spare capacity would be made. ${ }^{116}$

The December 2014 draft Resolution stipulates that gas transportation service is to be provided on the basis of a contract concluded between a gas transportation company and a consumer of transportation service. The contract must contain inter alia the following information: the intake, transportation and offtake mechanism, volumes and quality of gas to be transported, the intake and offtake points, the payment mechanism, rights and obligations of both parties, dispute settlement mechanism, force majeure, parties' responsibilities for failure to fulfil the terms of the contract in full or in part. It also contains a number of additional conditions (absent from the April 2012 draft) which must be included e.g. the mechanism for changing the volumes, dates, intake and offtake points. Importantly, the draft stipulates that the transportation contract must be a public document (Art. 5) (also absent from the April 2012 draft).

The gas transportation request must contain inter alia the following information (Art. 10): the intended transportation period, the intended volume of gas for transportation, firm and interruptible service, intake and offtake points, volumes of gas transportation for consumers within the consumption quota, for communal and social needs of citizens, for firm consumers (where production cannot be interrupted), consumers for which switching to alternative supplies is not envisaged, consumers for which interruption of supplies might lead to health hazards.

The request must be accompanied by the following documents (Art. 12):

- documents confirming either ownership rights of gas or other legal grounds for gas possession (with one of the documents listed below to be provided):

- subsoil use license, statement from project documentation on field development on annual production volumes,

- sale and/or purchase contract,

- contract for associated gas processing,

- documents confirming either presence of gas in storage or in high pressure pipelines or existence of gas purchase contracts,

- confirmation of an applicant's participation at the exchange to buy/sell gas in respect of which a request for capacity is made,

\footnotetext{
116 In contrast to this, the April 2012 draft safeguarded all Gazprom's and third parties' existing and future contracts in respect of supplies to certain categories of customers (e.g. for state and municipal purposes as well as for citizens' communal and social needs) and in respect of supplies under Russia's international agreements (contracts). The 2012 draft also safeguarded all Gazprom and third party contracts in respect of all categories of consumers which were concluded before the Resolution's entry into force.
} 

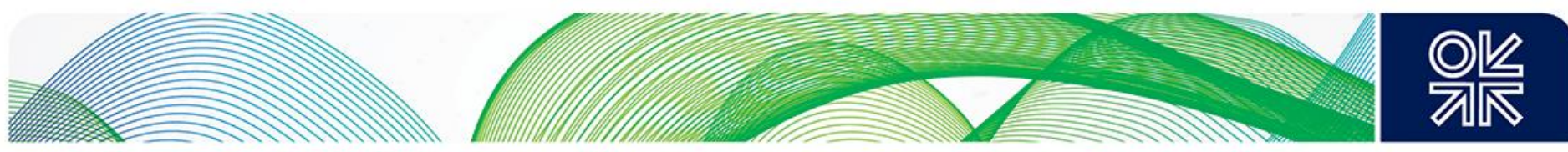

- confirmation of ownership rights (or other legal right of possession) for gas, including future rights; 117

- $\quad$ sale and/or purchase contracts for state or municipal needs, communal and social needs of citizens, any other evidence confirming that gas supplies are designated for such needs;

- foundation documents;

- $\quad$ statement from the state registry;

- authorisation, approved by an applicant, confirming the rights of an entity (acting on behalf of the applicant) to lodge a request and conclude a contract;

- confirmation from the gas distribution company and customer of their readiness to accept the gas;

- gas quality certificate.

The time schedule for submitting transportation requests is as follows:

- for long term transportation service (more than one year) - not earlier than three years and not later than three months before the first year when gas transportation is planned;

- for short term transportation service (less than or equal to one year) - not earlier than three months before and not later than thirty days before the start of the period when gas transportation service is planned to be used.

If correct documentation is provided, the gas transportation company does not have a right to refuse consideration of the request. The gas transportation company must return the documents to the applicant within 5 days, should the request not meet the requirements (Art. 13). The time frame for consideration of a request is two months for long term capacity requests and fifteen days short term capacity (Art. 13-14). Having considered the request, the gas transportation company either grants it in full, both in respect of volume and duration, or in part (and provides justification), or as interruptible capacity, or refuses the request with justification for refusal. The transportation company has the right to refuse if spare capacity is not sufficient for granting the request fully or partially. Should the company grant the request, it must notify the applicant and send it a signed transportation contract. Once the contract is signed by the applicant, the contract is considered concluded. The applicant has the right to send the gas transportation company a protocol summarizing its disagreements with any refusal to sign the contract (Art. 16). Unjustified avoidance or refusal to conclude a contract can be appealed under Russian law; the onus of proving lack of technical capacity to transport lies with the gas transportation company (At. 20).

A long term capacity request is granted proportional to volumes requested for the first year of transportation, and proportional to volumes requested taking into account projections of capacity expansion in high pressure pipelines (for periods of transportation exceeding one year). Short-term capacity is granted proportional to volumes requested. The gas transportation company first decides on long term capacity requests and then on short term capacity requests, taking into account the decisions made in respect of the former.

The December 2014 Draft Resolution established the following capacity allocation mechanism in the event of spare capacity being insufficient for granting the request in full, such that a gas transportation company decides on granting the requests partially, proportionally to volumes requested and in the following order:

- suppliers of gas for communal and social needs of the residential sector, suppliers for transportation of associated gas;

\footnotetext{
${ }_{117}$ Notably both April 2012 and July 2014 drafts required evidence of ownership right existing at the time of making a request for capacity as opposed to ownership right appearing in the future.
} 

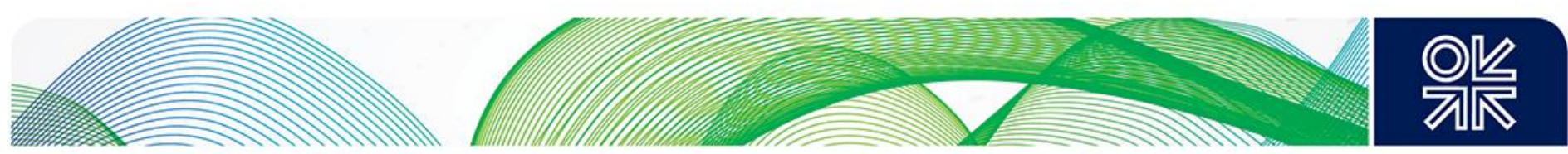

- entities which buy and sell gas at the exchange;

- suppliers envisaging supplies for longer periods.

The December 2014 draft prioritized supplies to the residential sector while also elevating supplies of associated gas to the same level (irrespective of consumer category for associated gas). However, having assigned the same priority to supplies to the residential sector and supplies of associated gas, the December 2014 draft did not make it clear which suppliers would be prioritized should there not be sufficient capacity for granting both requests. Unlike the July 2014 draft, which prioritized supplies to all domestic customers, the December 2014 draft Resolution only prioritized supplies for domestic communal and social needs. Also unlike the July 2014 draft, the December 2014 draft did not prioritize export supplies, while prioritizing supplies under long(er) term supplies instead, irrespective of whether they are intended for export or domestic consumption.

Importantly, in the December 2014 draft, the capacity access rules (procedure and times frames for requests and transportation contracts) do not apply to supplies of gas acquired at the exchange, which suggests the lack of clarity on part of the government on regulatory treatment of such supplies (envisaged to be around $35 \mathrm{bcm}$ per year as of 2015, see Section 2.1). ${ }^{118}$

In addition to developing the rules on access to UGS and non-UGS systems, the FAS has also prepared draft rules establishing the mechanism for connection (of pipelines or other objects) to high pressure pipelines. ${ }^{119}$ Under the December 2014 draft, connection is to be made on the basis of a contract, concluded between a gas transport company, which has the high pressure pipeline in its possession (on the basis of ownership or other legal grounds), and an entity, which possesses the gas (on the basis of ownership or other legal grounds), or an entity which intends to produce, supply or process gas (Art. I.4). Thus, possession of gas is not necessary for making a connection request. $^{120}$

The connection request must contain inter alia the information on envisaged connection points, maximum daily supply/consumption volume, pipeline and/or facility construction time frame, and a gas supply/offtake time frame (Art. II.7). According to the draft, the only possible reason for a gas transportation company to refuse connection is an absence of technical connection possibility. Technical possibility to connect exists when there is spare capacity in the high pressure pipeline (Art. II.17). Should this be absent, the refusal must contain information on the schedule when it may be available in future, should the gas transportation company undertake certain measures in this regard which would be financed by external (including the state budget) funds, as well as other possibilities including the possibility of connection on the basis of capacity trading or release agreements.

In the event of justified refusal, the entity which requested connection, can confirm to the gas transportation company its readiness to carry out technical connection as an individual project, with full compensation of all expenses incurred. The draft rules further stipulate that new infrastructure contributing to the creation of spare capacity necessary for enabling technical connection, cannot be transferred under the gas transportation company ownership without consent of an entity, which paid for its construction (Art. II.30).

\footnotetext{
${ }^{118}$ See Gazprom deputy CEO, Valerii Golubev's comments on this. 'Gazprom worried exchange trading in Russia will harm gas offtake in its contracts', Interfax Russia \& CIS Oil and Gas Weekly, 11-17 December 2014.

${ }^{119}$ Draft Resolution on the rules of non-discriminatory access to services to transport gas through high pressure pipelines and on the rules on connection to high pressure pipeline, 11 December 2014,

http://base.consultant.ru/cons/cgi/online.cgi?req=doc;base=PNPA;n=5359

${ }^{120}$ E.g. Rosneft has requested Gazprom to connect Rosneft's planned Eastern Oil and Chemical Company (EOCC) to the SKV pipeline. Under the draft rules Rosneft would not be required to demonstrate that it possesses the gas as long as it can prove that it intends to construct the EOCC.
} 

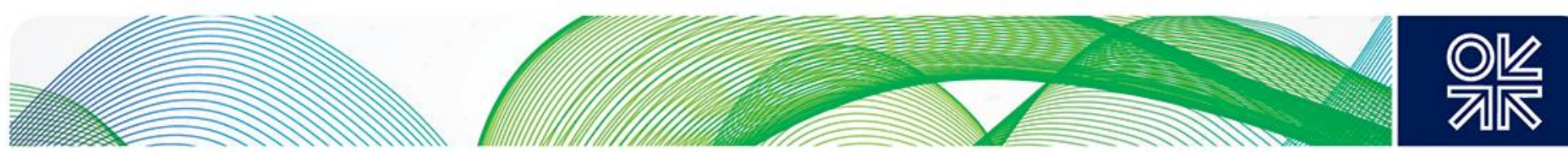

\section{Transportation Tariffs}

\subsection{Regulated Tariffs}

In 2000, government Resolution No 1021 mandated the Federal Tariff Service (FTS), ${ }^{121}$ together with the Ministry of Economic Development and Trade (MEDT), to develop methodological tariffication principles. The Resolution also mandated the FTS, together with the MEDT and Gazprom, to develop a corresponding methodology; ${ }^{122}$ the methodology was adopted in $2005 .{ }^{123}$

Transmission tariffs, as set by FTS methodology, are charged by owners of gas supply networks (UGS and non-UGS) to third parties for transportation of their gas through these networks, as well as to themselves in respect of gas which they produce, the prices for which are not regulated. (Importantly, it is only the prices at which Gazprom sells gas to its customers that are regulated except the volumes sold at the exchange, see Sections 2.1 and 3.3 - whereas other suppliers' gas prices are not regulated). According to the methodology these tariffs are also to be charged for transportation of gas through third party pipelines. Thus, effectively, these regulated tariffs apply to all domestic transportation except for gas produced and transported by owners of UGS and non-UGS networks through their own networks, which is sold at regulated prices.

The methodology introduced a two-part tariff, ${ }^{124}$ which consisted of:

a) a fee charged for usage of the UGS which is set depending on the zones where the gas entered and exited the system measured in currency units per mcm and

b) a fee charged for transportation (measured in currency units per $\mathrm{mcm} / 100 \mathrm{~km}$ ). ${ }^{125}$

\footnotetext{
${ }^{121}$ Known as the Federal Energy Commission (FEC) under the responsibility of the Ministry of Economic Development and Trade (MEDT) prior to 2004, when it was renamed as the Federal Tariff Service (FTS) and placed under the direct responsibility of the Prime Minister office, see Stern (2005), p180.

${ }^{122}$ Resolution on state regulation of gas prices, transportation tariffs and connection to distribution networks, No 1021, 29 December 2000, http://base.consultant.ru/cons/cgi/online.cgi?req=doc;base=LAW; $n=172053$

${ }^{123}$ FTS order on approving the methodology for calculating tariffs charged for gas transportation through high pressure pipelines, 23 August 2005 No 388-э/1 (with amendments of 07 November 2006 No 245-э/2, 25 October 2007 No 286-э/4, 17 September 2008 г. No 174-э/6, 02 December 2011 No 315-э/10, 21 October 2014 No 230-э/1), http://base.consultant.ru/cons/cgi/online.cgi?req=doc;base=LAW; $\mathrm{n}=171176$

${ }^{124}$ FTS Information Bulletin (in Russian), No 16 (246), 2 May 2007.

${ }^{125}$ The fee charged for transportation is set at RR $12.79 / \mathrm{mcm} / 100 \mathrm{~km}$ for transportation in Russia and other Customs Union countries and at RR $14.16 / \mathrm{mcm} / 100 \mathrm{~km}$ for transportation outside, and has remained unchanged since July 2013. Presumably the fee charged for transportation of gas outside Russia and other Customs Union (CU) countries refers to gas which is transported within the territory of Russia and other CU countries but is designated for consumers outside Russia \& CU. See FTS order on approving tariffs charged from third parties for transportation of gas through Gazprom high pressure pipelines, which are part of the UGS system, 14 May 2014, N 109-э/2 (as amended by FTS Order of 29 December 2014 No 314-э/1) http://base.consultant.ru/cons/cgi/online.cgi?req=doc;base=LAW;n=175432 and FTS order on approving tariffs charged from third parties for transportation of gas through Gazprom high pressure pipelines, which are part of the UGS system, 4 July 2013, No 127-э/1 http://base.consultant.ru/cons/cgi/online.cgi?req=doc;base=LAW; $n=149371$; fld=134;from=164318-

$18 ;$ rnd $=0.3879612784221072$
} 

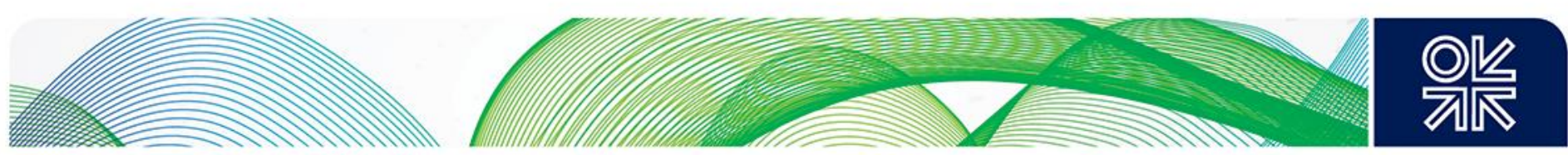

However, one-part tariffs are applied if no compression of gas occurs during transportation, or if the share of the cost of gas and power for operating the pipeline is not above one per cent of the total cost of transportation; a one-part tariff may also be used for regional gas supply systems.

A one-part tariff and the fee charged for transportation as part of the two-part tariff, are both set based on volume of gas transported (i.e. transportation per $\mathrm{mcm}$ ) if gas is transported through the same route for all shippers; ${ }^{; 26}$ otherwise both are set based on distance (i.e. $\mathrm{mcm} / 100 \mathrm{~km}$ ).

The fee charged for usage of the system as part of the two-part tariff itself consists of two parts fixed ${ }^{127}$ and variable. The variable part of the tariff is complex, and is calculated on the basis of a matrix of weighted average transportation distances between all zones of entry and exit, with special coefficients applied to ensure that the cost of gas (including the cost of transportation) is directly dependent on distance. A special model optimizes transportation flows from certain entry zones to certain exit zones by minimizing a total volume of transportation in the UGS system as a whole. ${ }^{128}$

It is worth stressing that the Russian tariff methodology is not an "entry-exit" methodology (where a shipper pays an entry charge to enter a zone and an exit charge to leave it) as defined and understood in EU regulation. ${ }^{129}$ The Russian methodology is essentially zonal, where a shipper needs to pay a fee for usage of the system which takes into account where the gas enters and where it leaves, plus a fee (either distance or volume related) for transportation. It is estimated that usage constitutes around $70-80 \%$, and transportation around $20-30 \%$, of total revenue.

According to this methodology, a zone of entry into the system consists of:

- all entry (inflow) points to high-pressure pipelines from gas fields, gas processing plants, gas storages and other sources;

- all cross-border points (in case of transport of gas from storages outside Russia).

A zone of exit from the system consists of:

- all exit (outflow) points from high-pressure pipelines (several zones of exit can be created in those regions where unidirectional transportation distance is above $400 \mathrm{~km}$ );

- all connections points of national storages,

- all cross-border points on the sections adjacent to a Russian region.

Borders of a zone (i.e. grouping of the connection points into one zone) are set in such a way as to achieve an optimal distance between the furthest points (up to $100 \mathrm{~km}$ ) and allowing pipelines belonging to one corridor to be grouped into one entry zone, while also taking into account the Russian regional borders and the borders of gas transmission companies (i.e. Gazprom Transgaz companies).

\footnotetext{
${ }^{126}$ This tariff design is also allowed for regional supply systems.

${ }^{127}$ Does not depend on distance but reflects the cost of gas distribution; not charged if gas does not go through a gas distribution station at the end of its route of transportation (e.g. transportation to balancing points where gas is sold at the electronic trading platform, transportation to storages); it is also not charged if a gas distribution station does not belong to Gazprom.

${ }^{128}$ FTS Information Bulletin (in Russian), No 11 (385), 26 March 2010; FTS order No 109-э/2, 14 May 2014.

${ }^{129}$ With the EU consisting of a number of zones the borders of which have not been defined yet and which may or may not correspond to EU member states' borders, see Yafimava (2013).
} 

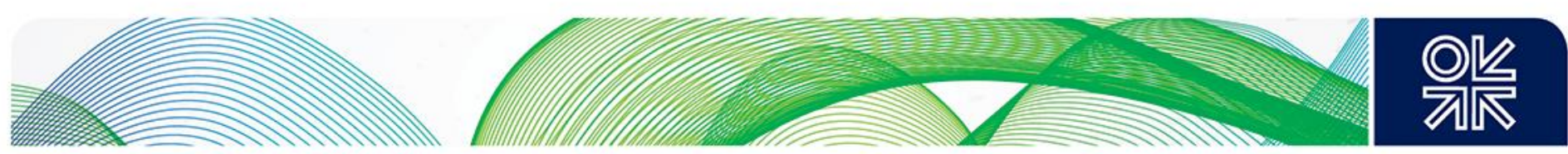

The FTS order on tariffs for third parties, adopted in May 2014, lists the following zones of entry from: ${ }^{130}$

- 18 gas producing fields/regions (Yamburg, Purovskaya, Urengoy, Pangody, Tarkosale, Gubkinskaya, Vyngapur, Taezhnaya, Nizhnevartovskiy, Vertykos, Vuktyl, Orenburg,

Astrakhan', Lokosovo, Yuzhno-Balyksk, Zapoliarnoye, Bovanenkovskoye, Berezovskoye;

- compressor stations in producing areas (Nadym, Vyngapurovskaya, Yagelnaya, YuzhnoBalykskaya, Parabel);

- storages (Kanchurinsko-Musinskiy, Severo-Stavropolskoye, Kushevskoye, Gatchinskoye, Nevskoye, Kaluzhskoye, Kasymovskoe/Uviazovskoe, Karashurskoye, Punginskoe, Sovkhoznoe, Saratovskoe, Krasnodarskoye, Shelkovskoye, Samarskie).

And the following zones of exit from:

- $\quad$ sixty five Russian regions (including the cities of Moscow and St Petersburg); ${ }^{131}$

- compressor stations in producing areas (the same as for entry, see above);

- storages (the same as for entry, see above);

- gas metering stations installed on Russia's international borders with:

- Customs Union countries: Smolensk (Russia/Belarus), Aleksandrov Gai

(Russia/Kazakhstan), Alekseevskaya (Russia/Kazakhstan), Kartaly

(Russia/Kazakhstan),

- Non-Customs Union countries: Imatra (Russia/Finland), Izborsk (Russia/Estonia),

Smolensk (Russia/Belarus), Sudzha (Russia/Ukraine), Valuiki (Russia/Ukraine),

Serebrianka (Russia/Ukraine), Pisarevka (Russia/Ukraine), Sokhranovka

(Russia/Ukraine), Platovo (Russia/Ukraine), Beregovaya (Russia/Turkey) Novo-Filya

(Russia/Azerbajan), ChMl (Russia/Georgia).

A fee for usage of the system is set for most of the pairs of entry and exit zones (currency units per $\mathrm{mcm}$ ) and varies depending on the entry-exit pair. For example, in line with the May 2014 FTS order, ${ }^{132}$ for gas entering at Yamburg and exiting at various Russian regions, the fee was in the range of RR 582.85-1,970.45/mcm (\$19-66); ; 133 and exiting at various Russian gas storages, the fee was in the range of RR $1101.06-1,948.71 / \mathrm{mcm}(\$ 37-65)$. For those pairs of zones where a usage fee is not defined, a sliding scale of fees for each distance is provided from RR $57.18 \mathrm{mcm}$ (for $10 \mathrm{~km}$ ) to RR $2,048.11 / \mathrm{mcm}$ (for $4680 \mathrm{~km}$ ).

Below, as an example, we calculate a transportation tariff, which would be charged for transportation of one $\mathrm{mcm}$ of gas across $2,400 \mathrm{~km}$ (which is an average transportation distance for gas to a domestic Russian customer) on the basis of the May 2014 FTS order. ${ }^{134}$ Given the fee for transportation is RR $12.79 / \mathrm{mcm} / 100 \mathrm{~km}$ and a fee for usage is RR $1,278.09$ (based on $2,400 \mathrm{~km}$ distance, assuming that a usage fee for a given entry-exit pair is not defined), a total charge for transporting one mcm of gas across $2,400 \mathrm{~km}$ is RR $1,585(12.79 * 24+1,278.09)(\$ 53)$. Another way of defining it could be to sum a fee for transportation and a fee for usage for an entry-exit zone, the

\footnotetext{
${ }^{130}$ FTS Order No 109-э/2, 14 May 2014.

${ }^{131}$ Some of these regions are further divided into several zones.

${ }^{132}$ FTS Order No 109-э/2, 14 May 2014.

${ }^{133}$ In this paper all conversions from Russian roubles into US dollars are made at the exchange rate $\$ 1=$ RR 30 (which was the average rate before the second half of 2014, since when the Russian rouble has lost around half of its value; as this paper goes into press the conversion rate stands at around $\$ 1=\mathrm{RR} 60$.

${ }^{134}$ FTS Order, 14 May 2014, No 109-э/2.
} 

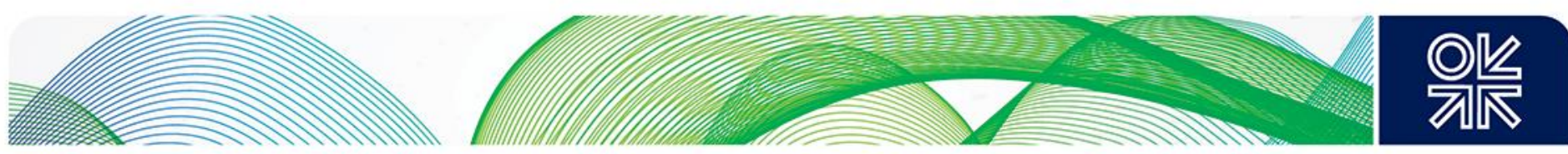

length of pipelines within which is approx $2,400 \mathrm{~km}$ (e.g. Yamburg-Tatarstan). The tariff would be RR $1,620(12.79 * 24+1,312.63)$ (approx. \$ 54).

Table 3 shows average level of tariffs, charged by Gazprom to third parties, as calculated by FTS. A transportation charge derived by multiplying the average tariff of $62 \mathrm{RR} / \mathrm{mcm} / 100 \mathrm{~km}$ by $2,400 \mathrm{~km}$ would amount to RR 1,499 per mcm (approx. \$50).

Table 3: Average Level of Transportation Tariffs Charged by Gazprom to Third Parties

\begin{tabular}{|l|l|l|}
\hline Date of entry into force & $\begin{array}{l}\text { In Russia and other Custom } \\
\text { Union countries } \\
(\mathrm{RR} / \mathrm{mcm} / 100 \mathrm{~km})\end{array}$ & $\begin{array}{l}\text { Outside Custom Union countries } \\
(\mathrm{RR} / \mathrm{mcm} / 100 \mathrm{~km})\end{array}$ \\
\hline 1.10 .2004 & 19.37 & $\$ 0.92$ \\
\hline 1.10 .2005 & 23.84 & $\$ 0.97$ \\
\hline 1.08 .2006 & 26.40 & 29.00 \\
\hline 1.03 .2007 & 30.36 & 33.35 \\
\hline 1.01 .2008 & 36.13 & 40.02 \\
\hline 1.01 .2009 & 37.86 & 41.94 \\
\hline 1.04 .2009 & 40.44 & 44.79 \\
\hline 1.07 .2009 & 43.19 & 47.84 \\
\hline 1.10 .2009 & 45.74 & 50.66 \\
\hline 1.01 .2010 & 51.37 & 56.90 \\
\hline 1.01 .2011 & 56.15 & 62.19 \\
\hline 1.07 .2012 & 58.12 & 64.36 \\
\hline 1.07 .2013 & 62 & 68.67 \\
\hline
\end{tabular}

Source: FTS Information Bulletin № 11 (385), 26 March 2010; FTS Report on 2013 results and mid-term tasks, 2014.

Since the methodology was first introduced in 2005, tariffs have been regularly revised upwards (at a rate slightly below the rate of increase in wholesale gas prices and below the inflation rate). In doing this the FTS appears to have taken Gazprom's concerns into account. Gazprom has long called for increases, arguing that tariffs remained below the economically justified level of RR $75 \mathrm{mcm} / 100 \mathrm{~km}$ (around \$2.5), which would suggest an average transportation charge of RR 1,800/mcm (approx. $\$ 60) .{ }^{135}$

Given that the regulated gas price for industry in 2014 constituted RR $3,772 \mathrm{RR} / \mathrm{mcm}$ (approx. $\$ 125)^{136}$ it is possible for independent producers to sell gas to customers profitably as their cost of production is relatively low. This is a significant change compared to the mid-2000s when this would not have been possible given the much lower regulated gas price for industry (although the transportation charge was also lower). ${ }^{137}$ As a result, the 'economic radius' for gas sales from the point of production (within which distance it is profitable for third parties to sell their gas to customers) has more than doubled in the 2007-2014 period. This suggests that notwithstanding third party complaints about Gazprom's reluctance to transport their gas, and the aforementioned concerns about tariff methodology, significant progress in enforcing non-discriminatory access rights has been made during the last decade. This conclusion is also supported by the data on the increasing share of third party gas transportation (Table 2).

\footnotetext{
${ }^{135}$ According to Gazprom the share of its revenues derived from transportation services rendered for third parties constituted only $3 \%$ of total sales revenue in 2012; see Gazprom Preliminary Bond Prospectus. 12 July 2013, p. 70.

${ }^{136}$ FTS Information Bulletin, No 13 (579), 4 April 2014, p. 19.

${ }^{137}$ Stern (2005), p.180.
} 

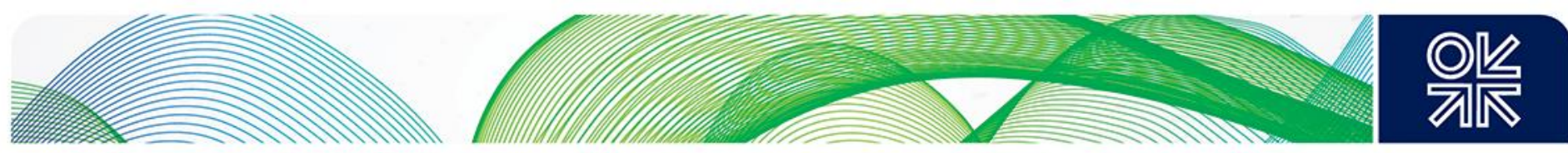

\subsubsection{Critique of the Tariff Methodology}

Although the tariff methodology described above is very sophisticated, it nonetheless fails to address a number of aspects of third party transportation, particularly in respect of cost-reflectivity, capacity allocation, and determination of optimal routes for third party gas.

As far as cost reflectivity is concerned, the FTS methodologies for calculating both a one-part tariff and a two-part tariff take into account the costs incurred by the Gazprom Transgaz companies for transportation of third party gas through the UGS system, plus taxes and profit. However, the methodology does not explain how these costs are calculated. This lack of transparency has been a recurrent complaint of third parties, who argue that the costs are artificially high leading to higher tariffs. It is impossible to know whether or not this is true precisely because the cost base is not transparent. For example, there has been an increase in third party complaints suggesting that regulated tariffs include the costs incurred by Gazprom in respect of the construction of exportoriented pipelines, despite the third parties' inability to export pipeline gas due to the Gazprom monopoly. ${ }^{138}$

Apart from the perceived lack of cost-reflectivity, third parties have also complained about Gazprom's determination of route selection, because it is not required by law to transport third party gas by the shortest route. As a result, third parties could find themselves paying a higher tariff because of the potentially circuitous routes selected for them by Gazprom. Although it is a valid concern, and whereas third parties would have preferred their gas being transported by the shortest route, doing so might not necessarily support optimization of flows and minimization of the total volume of transportation in the UGS system - the objective around which the FTS tariff methodology is built. At the same time, it is impossible to determine whether Gazprom might not be offering the shortest route to a third party because it is not an optimal solution, or because it wants to use this route for transportation of its own gas.

Another important issue, which does not appear to be addressed by the existing methodology is how capacity is allocated to shippers in the event there is insufficient capacity on a specific route to satisfy all third party requests. The draft resolutions on non-discriminatory access contain various capacity allocation mechanisms to be applied in this situation (Section 2.3). The December 2014 draft suggests an order of priorities from the residential sector and supplies of associated gas, to supplies of gas acquired at the exchange and longer term supplies.

\subsection{Tariffs Charged to Gazprom for Transportation of its Own Gas Sold at Regulated Prices}

While transporting its own gas, which it is required to sell at regulated prices, Gazprom also charges itself a transportation tariff, the levels of which it sets itself internally - these charges are not regulated. ${ }^{139}$ (In respect of Gazprom's sales at unregulated prices, regulated transportation tariffs

\footnotetext{
${ }^{138}$ It must be noted though that some pipelines have both domestic and export elements e.g. the Southern Gas Corridor system in the southern Russia, the main purpose of which was to carry gas to the Black Sea coast to supply gas for the South Stream export pipeline and, following its cancellation, for the Turkish Stream pipeline.

${ }^{139}$ A price list No 04-03-28-2005 'Internal calculated (wholesale) gas prices and internal transportation and storage tariffs for Gazprom entities'; a price list (additional) No 04-03-28-2009/1 'Internal calculated (wholesale) gas prices and internal transportation and storage tariffs for Gazprom entities'.
} 
apply, see Section 3.1). Table 4 shows these internal transportation tariffs in 2005 and 2009. Third parties commonly complained in the 2000s that they 'were being forced to pay a regulated transportation tariff far higher than Gazprom charged itself for transportation', and claimed that Gazprom charged itself 'between one-third and one-quarter of the regulated tariff. But comparison of the regulated tariff of $19.37 \mathrm{RR} / \mathrm{mcm} / 100 \mathrm{~km}$ charged to third parties with the tariff charged by Gazprom to itself (Tables 3 and 4) suggests that only in very few instances was Gazprom's internal tariff significantly lower than the regulated tariff charged to third parties (e.g. Tyumen-Transgaz, Perm'-Transgaz, Tat-Transgaz). In most instances it appears to have been on a par with the regulated tariff, and in some instances even significantly higher (Kuban'-Gazprom, Tomsk-Transgaz, Astrakhan'-Gazprom).

Table 4: Internal Transportation Tariffs charged by Gazprom to its Transmission Companies, 2005 and 2009

\begin{tabular}{|l|c|l|c|}
\hline $\begin{array}{l}\text { Gazprom's } \\
\text { Transmission }\end{array}$ & $\begin{array}{c}\text { Tariff for } \\
\text { transportation, } \\
\text { RR/mcm/100 km }\end{array}$ & $\begin{array}{l}\text { Gazprom's } \\
\text { Transmission } \\
\text { Companies, 2009 }\end{array}$ & $\begin{array}{c}\text { Tariff for } \\
\text { transportation, } \\
\text { RR/mcm/100 km }\end{array}$ \\
\hline Sever-Gazprom & 26.54 & Gazprom Transgaz Ukhta & 42.68 \\
\hline Kuban'-Gazprom & 101.50 & Gazprom Transgaz Krasnodar & 101.8 \\
\hline Surgut-Gazprom & 26.55 & Gazprom Transgaz Surgut & 50.79 \\
\hline Tyument-Transgaz & 14.60 & Gazprom Transgaz Yugorsk & 30.2 \\
\hline Len-Transgaz & 35.22 & $\begin{array}{l}\text { Gazprom Transgaz St } \\
\text { Petersburg }\end{array}$ & 68.52 \\
\hline Mos-Transgaz & 18.15 & Gazprom Transgaz Moskva & 39.27 \\
\hline Tomsk-Transgaz & 102.30 & Gazprom Transgaz Tomsk & 147.13 \\
\hline Perm'-Transgaz & 10.84 & Gazprom Transgaz & 19.93 \\
& & Tschaikovsky & 42.7 \\
\hline Ural-Transgaz & 26.42 & Gazprom Transgaz Ekaterinburg & 38.78 \\
\hline Bash-Transgaz & 21.69 & Gazprom Transgaz Ufa & 71.34 \\
\hline Kavkaz-Transgaz & 40.46 & Gazprom Transgaz Stavropol' & 27.8 \\
\hline Volgo-Transgaz & 16.64 & Gazprom Transgaz Nizhnii & Novgorod \\
\hline Yug-Transgaz & 33.52 & Gazprom Transgaz Saratov & 51.49 \\
\hline Tat-Transgaz & 11.93 & Gazprom Transgaz Kazan' & 20.69 \\
\hline Samara-Transgaz & 17.92 & Gazprom Transgaz Samara & 34.88 \\
\hline Volgograd-Transgaz & 22.45 & GazpromTransgaz Volgograd & 36.3 \\
\hline Kaspii-Gazprom & 61.30 & Gazprom Transgaz Mahachkala & 149.88 \\
\hline Astrakhan'-Gazprom & 119.00 & & \\
\hline
\end{tabular}

Note: In 2005 Gazprom began reorganizing its 18 transmission companies, turning them into 17 Gazprom Transgaz companies (hence the different names in 2005 and 2009); it is not clear whether the borders of their zones of responsibility have changed significantly in the process but the names of new resulting companies suggest that they probably cover more or less the same pipeline geography as the old transmission companies. One noticeable change is the disappearance of Kaspii-Gazprom and Astrakhan'-Gazprom and the appearance of Gazprom Transgaz Makhachkala.

Sources: for 2005 - a price list No 04-03-28-2005 'Internal calculated (wholesale) gas prices and internal transportation and storage tariffs for Gazprom entities', www.ngvrus.ru/docs/preyskurant.pdf, accessed 8 March 2014; for 2009 - adopted from The Institute of Natural Monopolies Problems 'Cost of gas transportation through different export routes' (citing a price list (additional) No 04-03-28-2009/1 'Internal calculated (wholesale) gas prices and internal transportation and storage tariffs for Gazprom entities', http://ipem.ru/images/stories/Files/gaz/2_conoco.pdf, accessed 8 March 2014. 

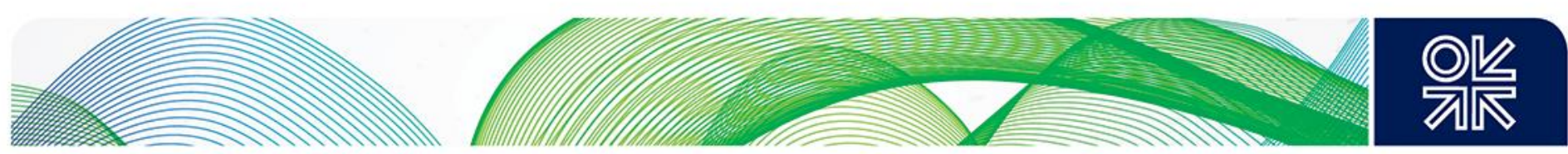

No data on Gazprom's post-2009 internal transportation tariffs is available in the public domain, but according to the protocol of the Presidential Energy Commission meeting, in 2014 these tariffs were on average $15 \%$ lower than regulated transportation tariffs. ${ }^{140}$ At the Commission meeting. President Putin stated that the level of tariffs charged to Gazprom and third parties should be equal. ${ }^{141}$ This could be done either by increasing Gazprom's tariffs to the level of regulated tariffs, or by introducing regulation of Gazprom's tariffs. The FAS deputy head, Alexei Golomolzin, has argued in favour of the latter, proposing to develop common principles of tariff calculation for Gazprom and third parties. ${ }^{142}$ However, the FTS deputy head, Sergei Novikov, stressed that the FTS is only empowered to regulate transportation tariffs for non-Gazprom companies, and hence any change in Gazprom's internal transportation tariffs is outside its mandate.

\subsection{Regulated Transmission Tariffs vs Regulated Gas Prices}

The level of regulated transportation tariffs needs to be considered against the background of domestic gas prices. The Russian domestic gas market consists of regulated and unregulated segments: gas produced and marketed by Gazprom domestically is sold primarily at regulated prices, whereas gas produced by non-Gazprom producers is sold at unregulated prices (which can be either above or below regulated prices).

In November 2006, President Putin and the government announced a new pricing strategy, which aimed at increasing domestic gas prices to European levels on a netback basis. ${ }^{143}$ This was initially planned to be achieved by 2011 (based on the assumption of an oil price of $\$ 50-55 /$ barrel). ${ }^{144}$ Resolution No 333 adopted in 2007 mandated that, beginning from January 2011, gas produced by Gazprom is to be supplied to all categories of domestic customers (excluding the residential sector) at a regulated wholesale price calculated on the basis of a formula, ${ }^{145}$ approved by the FTS in $2007 .{ }^{146}$ The formula calculated the European netback price i.e. the price which would ensure equal profitability of domestic and export sales; regulated prices during the 2007-10 period were to be calculated at a discount (different for each year) to European netback price. Resolution No 333 also fixed the volumes of regulated gas sales at the levels supplied in 2007, allowing Gazprom to sell its gas a) under new contracts for supplies beginning in July 2007 and b) under existing contracts in respect of volumes exceeding the volumes agreed in these contracts, at a so-called 'regulated plus' price with the FTS capping the upper threshold. (In 2011 that threshold was equal to $10 \%$ of the regulated price).

Because of the sharp increase in oil (and hence gas) prices during the 2006-12 period (resulting in Gazprom's oil-linked netback price increasing to $\$ 230 / \mathrm{mcm}$ thus becoming more than two times above domestic price), and because of the economic crisis and financial recession of 2008, the Russian government pushed back the 2011 'deadline' for transition to European netback. Resolution No 1205, adopted in December 2010, extended the transition period until the end of 2014 with

\footnotetext{
140 'The meeting of the Presidential Energy Commission on strategy for energy sector development and environmental security' (transcript, in Russian), 4 June 2014.

${ }^{141}$ Ibid.

${ }^{142}$ FAS, 'Anatoly Golomolzin on the concept of developing the domestic gas market', 27 October 2014, http://en.fas.gov.ru/news/news_34029.html

${ }^{143}$ For the early developments of Russian gas price reform see Henderson (2011).

${ }^{144}$ Henderson and Pirani (2014), pp.120-121.

${ }^{145}$ Resolution on improving state regulation of gas prices, No 333, 28 May 2007,

http://base.consultant.ru/cons/cgi/online.cgi?req=doc;base=LAW; $n=110862$

${ }^{146}$ FTS Order, 05 July 2007, No 156-э.
} 

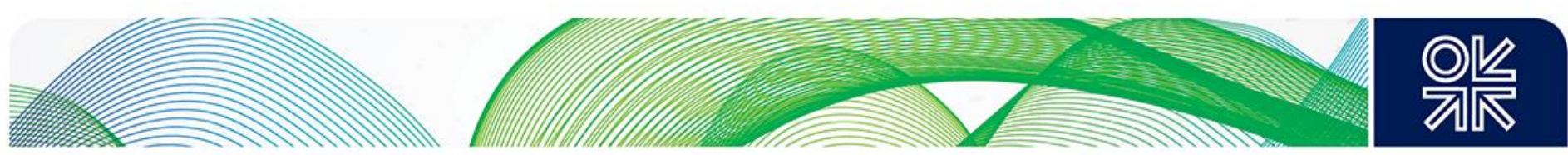

regulated prices for all consumers (excluding the residential sector) continuing to be set at a discount to European netback. ${ }^{147}$

In line with Resolution No 1205, the FTS approved a new formula with wholesale prices for Gazprom's domestic gas sales (excluding the residential sector) to be set in line with this formula from 2012. Prices for gas a) sold under new contracts for supplies beginning in July 2007 and b) under existing contracts in respect of volumes exceeding the volumes agreed in these contracts, were to continue to be sold at a 'regulated plus' price. ${ }^{148}$ Resolution No 1205 was amended in April 2014, whereby the transition period was extended until the end of 2017. ${ }^{149}$ The goal of abandoning regulation of gas prices and replacing it with regulation of gas transportation tariffs was also pushed back to the end of 2017.

On the other hand, third parties, which are allowed to sell gas at unregulated prices, have been selling their gas at a discount to regulated price ('regulated minus') thus taking away Gazprom's customers and reducing its market share. Between 2008 and 2013 the share of third parties' sales in the domestic production has increased from 17.3 to $27 \%$. As a result, Gazprom has argued that it too should be allowed to sell its gas at a discount, enabling it to compete with third parties.

The government has been considering Gazprom's request since 2013 and the issue was also discussed at the meeting of the Presidential Energy Commission in June 2014. ${ }^{150}$ The Commission has expressed broad agreement with allowing Gazprom to provide a discount although suggestions were made that this should be conditional on:

- introduction of a single tariff for transportation of gas through the UGS system and for storage for Gazprom and third parties, ensuring equal profitability of domestic transportation and elimination of regional cross subsidy,

- $20 \%$ of total gas sales to be made at the exchange (this has since been revised to $10 \%$, see Section 2.1), with a view that in the future unregulated pricing would only take place at the exchange and trading platforms, but not as part of Gazprom's contracts with buyers;

- precise definition of Gazprom's rights and responsibilities in respect of provision of nondiscriminatory access. ${ }^{151}$

In September 2014 the FST submitted a draft decree to the government which would allow Gazprom to offer a discount of up to $15 \%$ of the regulated price to consumers with annual consumption in excess of $0.1 \mathrm{bcm} ;{ }^{152}$ the MEDT suggested that Gazprom should be allowed to offer a discount to all consumers irrespective of their consumption level. ${ }^{153}$ At the time of writing, this draft had not yet been approved.

In summary, Russian domestic gas price reform was planned to be accomplished in two stages. During the first stage, beginning from 2006, the Russian government has made a consistent effort to bring regulated domestic prices closer to the levels that would have been provided by supply and

\footnotetext{
${ }^{147}$ Resolution on improving state regulation of gas prices, No 1205, 31 December 2010.

http://base.consultant.ru/cons/cgi/online.cgi?req=doc;base=LAW; $=162054$

${ }^{148}$ FTS Order, 14 July 2011, No 165-э/2.

${ }^{149}$ Resolution on improving state regulation of gas prices, No 1205, 31 December 2010 as amended 15 April 2014.

150 'The meeting of the Presidential Commission on strategy for energy sector development and environmental security' (transcript, in Russian), 4 June 2014.

151 lbid.

152 Down from Gazprom's preferred rate of $20 \%$ and up from the Energy Ministry's suggested rate of $10 \%$.

153 'Draft decree for Gazprom to offer discount of up to 15\% of tariff service's price', Interfax CIS Oil \& Gas Weekly, 2 September 2014.
} 

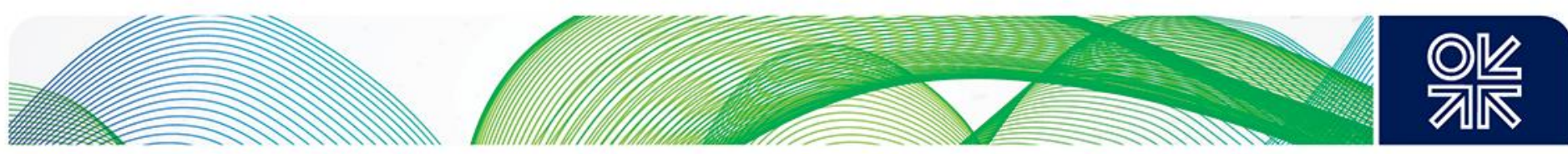

demand forces had those been allowed to be fully at play. During the second stage, the government was expected to increase regulated domestic prices to European netback levels; however implementation of this strategy (which was never workable) was initially delayed and de facto subsequently abandoned, with the government having realized the limited relevance of netback parity in the domestic context.

Also there has been increasing understanding on the part of the government of the necessity to 'discover' a genuine domestic gas price as defined by supply and demand forces (a consensus expert opinion being that the domestic market price would most likely be below regulated levels); this understanding manifested itself in the re-establishment of gas exchange trading in late 2014.

2014 has brought in a number of important new dynamics:

- a dramatic decline in European hub-based gas prices (thus increasing the gap between hub based and oil-linked price),

- a dramatic decline in global crude oil prices (thus decreasing the gap between hub-based and oil-linked prices, but with a time lag of 3-6 months),

- a dramatic decline in the Russian ruble exchange rate (thus increasing the gap between domestic regulated prices and European netback prices).

The combined net effect of these forces appears to be that by January 2015, the Russian domestic regulated price in equivalent US dollars was around six times below Gazprom's European prices and around four times below European hub-based prices.

Following the worsening of the economic situation in the second half of 2014, the Russian government has been reluctant to increase prices due to the potential adverse impact on consumers - this has been the main reason for the continuation/re-emergence of regulation. Thus even if state regulation of transportation tariffs charged both to Gazprom and to third parties is established, in theory removing the necessity of continued regulation of Gazprom's wholesale gas prices, in practice it is reasonable to expect price regulation to continue for some time. 

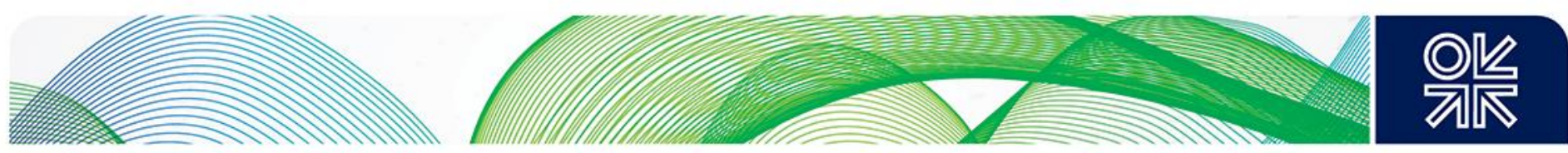

\section{Conclusions}

The reform of pipeline access regulation and gas transport tariffs in Russia has made significant progress since the late 2000s, especially in improving non-discriminatory access to the Gazpromowned UGS system, with the majority of third party requests being granted. The introduction in 2005 of new zonal tariff methodology (used for calculation of regulated tariffs charged to third parties for transportation of their gas through the UGS system) also addressed some third party concerns, although questions remain about Gazprom's choice of routes for third party gas and the methodology's cost-reflectivity, not least because of its lack of transparency. However, the legal framework governing access to the UGS system remains insufficiently developed both in scope (e.g. non-applicability to the non-UGS systems, storage, LNG infrastructure) and content (e.g. significant room for discretion in respect of choice of routes for third party gas and capacity allocation in the event of spare capacity deficit). There is limited scope for further improvement short of revising the framework itself.

Ensuring access to non-UGS system capacity has been more problematic due to the absence of a detailed legal/regulatory framework applicable to non-UGS systems. The existing general framework (The Law on Gas Supply and the Law on Competition) has proved insufficient, as demonstrated by continuing disputes between Gazprom and third parties (especially Rosneft) in respect of access to capacity in the new non-UGS pipelines - both existing and under construction - which comprise the Eastern Gas Programme (EGP). Inability to resolve these issues is an obstacle to the optimal development of eastern Siberian and Sakhalin gas which is seen by the government as a strategic priority for developing the depressed eastern regions, and strengthening Russia's competitive position, both as an LNG and pipeline gas exporter, in rapidly growing Asian gas markets (and especially China). The EU/US sanctions and a substantial decline in global oil prices in the secondhalf of 2014 severely limit the ability to progress EGP LNG projects, thus making optimal utilization of pipeline capacity based on non-discriminatory access increasingly important.

The Presidential Energy Commission has mandated the government to design a new concept for Russian gas market development, including a new legal/regulatory framework establishing the rules for non-discriminatory access to UGS and non-UGS systems. This framework, currently under discussion in the government, aims to address the aforementioned problems in respect of access and capacity allocation mechanisms. The December 2014 draft Resolution stipulates identical rules of access for Gazprom and third parties, whereby both would have to apply for spare capacity in UGS and non-UGS systems on equal terms. The draft safeguarded all Gazprom's and third parties' existing transport contracts, both for export and domestic supplies (irrespectively of consumer category) (at least) until their expiry. In the event of insufficient capacity, the draft prioritized supplies to the residential sector while also elevating associated gas supplies to the same priority level (irrespective of consumer category), followed by supplies of gas bought/sold at the exchange and longer term supplies (irrespective of whether these are for domestic use or export).

If adopted, the new Resolution will reinforce regulated non-discriminatory access to both UGS and non-UGS networks (replacing the previous mixture of negotiated and regulated access). However, the Resolution's reach will remain limited as long as the principle of UGS indivisibility remains in place. If it does, Gazprom will continue to remain in charge of provision and oversight of access to the UGS system for itself and third parties. Should the UGS be expanded by incorporating EGP's non-UGS systems, Gazprom's role would be further enhanced. Nonetheless, the Resolution's effectiveness could be improved through strengthened oversight by regulatory (FTS) and competition (FAS) authorities without dismantling the UGS indivisibility principle - which seems the most likely scenario.

From the Russian state's point of view, the aim of domestic gas market reform - including the reform of gas transportation regime - is to establish a level playing field for Gazprom and non-Gazprom 

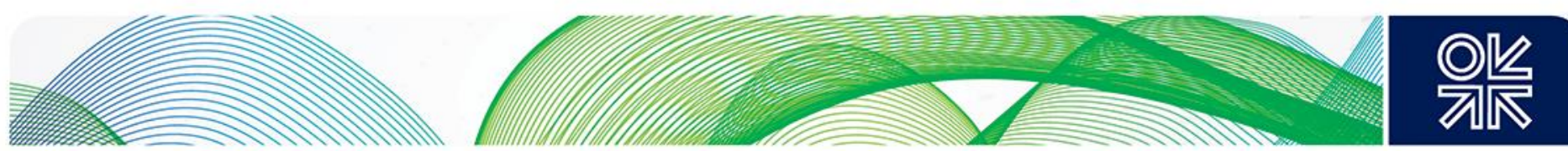

parties in order to ensure the optimal development of the domestic gas sector and the Russian economy as a whole, while preserving the country's competitive position as an exporter to both European and Asian gas markets. At present, these aims are to be achieved by increasing direct government involvement and strengthened FTS and FAS oversight. However, should these measures fail, with the following consequences:

- decline in the volume and the share of third party gas in the UGS system throughput,

- continuing inability of third party gas to access non-UGS system pipelines (especially those built under the EGP) provided spare capacity is available,

- failure to address concerns (if these are legitimate) in respect of limited cost-reflectivity of Gazprom's transportation tariffs, discrimination and preferential treatment in capacity allocation in the event of capacity deficit,

- lack of progress in the development of non-discriminatory access to storage and LNG infrastructure;

then more radical measures might be required. In such a situation it is not inconceivable that abolition of the UGS system indivisibility principle, with subsequent Gazprom ownership unbundling, might take place with (potentially) the state becoming the owner of UGS and non-UGS networks. In early 2015, as this paper is being completed, this seemed a 'last resort' measure which was not under consideration by the authorities. 

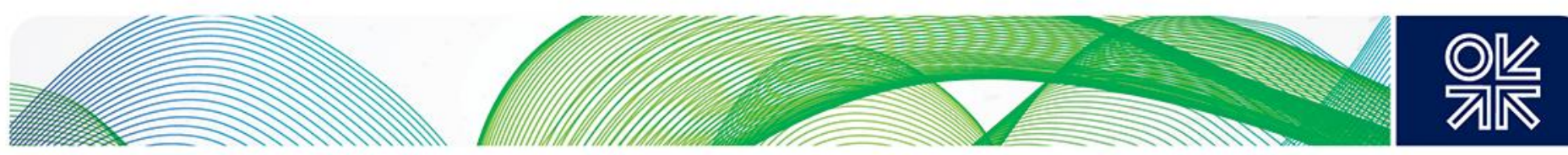

\section{Glossary}

\section{Abbreviations}

CNPC - China National Petroleum Corporation

EC - European Commission

EGP - Eastern Gas Programme

EOCC - Eastern Oil and Chemical Company

EU - European Union

FAS - Federal Antimonopoly Service

FTS - Federal Tariff Service (formerly FEC, Federal Energy Commission)

GTS - Gas Transportation System

LNG - Liquified Natural Gas

MEDT - Ministry of Economic Development and Trade (before 2008)

MED - Ministry of Economic Development (after 2008 the trade function was transferred to the Ministry of Industry)

OECD - Organisation for Economic Co-operation and Development

PSA - Production Sharing Agreement

SKV - Sakhalin-Khabarovsk-Vladivostok pipeline

TEP - Third Energy Package

TPA - third party access

UGS (system) - Unified gas supply (system)

US - United States

\section{Definitions}

Account unbundling - an unbundling regime under which the transmission system operator, where it is part of a vertically integrated undertaking, must keep separate accounts;

Legal unbundling - an unbundling regime under which the transmission system operator, where it is part of a vertically integrated undertaking, must be independent at least in terms of its legal form from other activities not relating to transmission;

Ownership unbundling - an unbundling regime under which the transmission assets must be owned by an independent entity.

\section{List of Sakhalin projects}

Sakhalin 1 - a PSA based production project, developing three oil and gas fields (Chayvo, Odoptu and Arkutun-Dagi) off the north east coast of Sakhalin Island in the Russian Far East, operated by Exxon Neftegas Limited (a subsidiary of Exxon Mobil), which holds a 30\% stake; other shareholders include RN-Astra (Rosneft affiliate) (8.5\%), Sakhalinmorneftegas-Shelf (Rosneft affiliate) (11.5\%), SODECO (Japanese buyers consortium) (30\%), ONGC Videsh Ltd (Indian state-owned oil company) $(20 \%)$; 

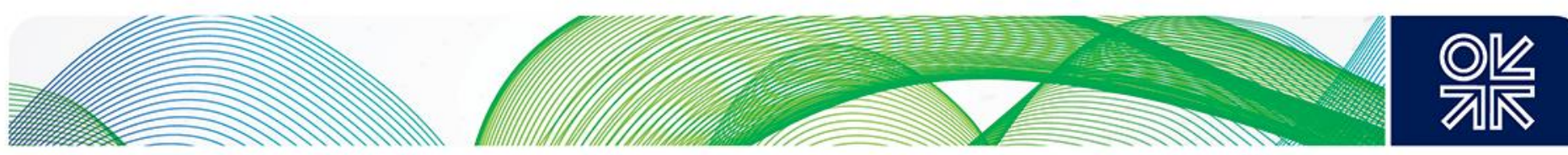

Sakhalin 2 - a PSA based production project, developing two oil and gas fields (Piltun-Astokhskoye and Lunskoye) off the north east coast of Sakhalin Island in the Russian Far East, operated by Sakhalin Energy Invest Company Limited ("Sakhalin Energy"), which shareholding consists of Gazprom (50\% plus 1 share), Shell $(27.5 \%$ minus 1 share), Mitsui (12.5\%), Mitsubishi (10\%);

Sakhalin 3 - a project based on several blocks off the north east coast of Sakhalin in the Russian Far East. Gazprom operates in three blocks: Kirinsky, Ayashsky and VostochnoOdoptinsky (the Kirinsky block comprises the Kirinskoye gas and condensate field as well as the Yuzhno-Kirinskoye and Mynginskoye gas and condensate fields). Rosneft operates the Veninsky block where it holds $74.9 \%$, the remaining $25.1 \%$ is held by Sinopec (Chinese state-owned oil and gas company). 

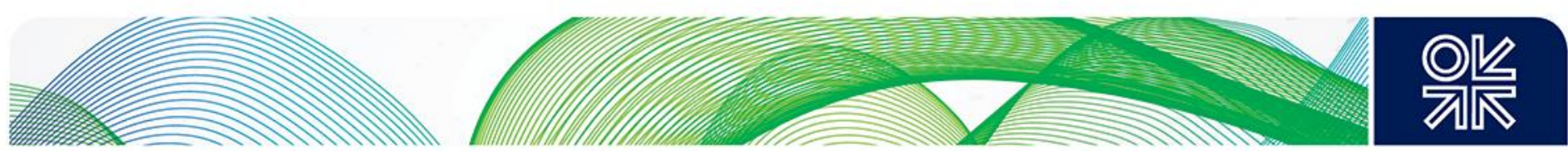

\section{Bibliography}

\section{Legislation}

* Presidential Decree N 1333, 'On Gazprom transformation from the state gas concern to the Russian joint stock company, 5 November 1992.

* The Law on Competition: Federal Law "On Competition in the Russian Federation" No 135Ф3, 26 July 2006 (with amendments up to 4 June 2014 No 143-Ф3).

* The Law on Gas Exports: Federal Law "On Gas Exports" No 117-Ф3, 18 January July 2006 as amended 30 November 2013.

* The Law on Gas Supply: Federal Law "On Gas Supply in the Russian Federation" No 69Ф3, 31 March 1999.

* Resolution No 858, On ensuring access of third parties to the Gazprom gas transportation system, 14 July 1997 (with amendments form 20 November 1999 No 1275, 02 November 2000 No 843, 03 May 2001 No 334, 16 April 2012 No 323, 19 June 2014 No 566).

http://base.consultant.ru/cons/cgi/online.cgi?req=doc;base $=\mathrm{LAW} ; \mathrm{n}=164592$

* Resolution No 1021, 'On state regulation of gas prices and transportation tariffs in the Russian Federation', 29 December 2000.

http://base.consultant.ru/cons/cgi/online.cgi?req=doc;base=LAW;n=172053

* FTS Order No 143-э/1, 8 June 2012.

* FTS Order on approving tariffs charged from third parties for transportation of gas through Gazprom high pressure pipelines, which are part of the UGS system, 14 May 2014, No 109э/2.

http://base.consultant.ru/cons/cgi/online.cgi?req=doc;base=LAW; $n=149371 ;$ fld $=134$;from $=164$ 318-18;rnd =0.3879612784221072

* Resolution No 333, On improving state regulation of gas prices, 28 May 2007. http://base.consultant.ru/cons/cgi/online.cgi?req=doc;base=LAW;n=171176

* FTS Order, 05 July 2007 No 156-э.

* FTS Order, 14 July 2011 No 165-э/2.

* FTS Order on approving tariffs charged from third parties for transportation of gas through Gazprom high pressure pipelines, which are part of the UGS system, 4 July 2013, No 127-э/1

* Draft Resolution 'The Rules on non-discriminatory access to high pressure pipelines in the Russian Federation', 11 April 2012, http://economy.gov.ru/wps/wcm/connect/ec61c7004ad85dc2a080abaf3367c32c/pp.pdf?MOD= AJPERES\&CACHEID=ec61c7004ad85dc2a080abaf3367c32c

* FTS Order, 14 May 2014, No 109-э/2.

* The July 2014 Draft Resolution: Draft Resolution on the rules of non-discriminatory access to services to transport gas through high pressure pipelines and the rules on connection to high pressure pipelines, 3 July 2014.

* FTS Order on approving the methodology for calculating tariffs charged for gas transportation through high pressure pipelines, 23 August 2005 № 388-э/1, with amendments of 7 November 2006 No 245-э/2, 25 October 2007 No 286-э/4, 17 September 2008 г. No 174-э/6, 2

December 2011 No 315-э/10, 21 October 2014 No 230-э/1.

http://base.consultant.ru/cons/cgi/online.cgi?req=doc;base=LAW;n=175432

* Resolution on improving state regulation of gas prices, No 1205, 31 December 2010, http://base.consultant.ru/cons/cgi/online.cgi?req=doc;base=LAW;n=162054 

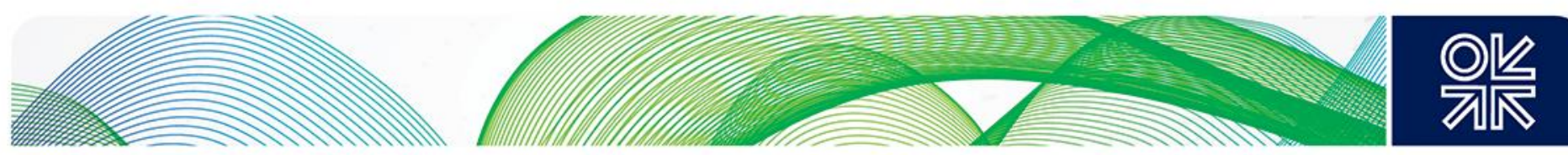

* The December 2014 Draft Resolution: Draft Resolution on the rules of non-discriminatory access to services to transport gas through high pressure pipelines and the rules on connection to high pressure pipelines, 11 December 2014, http://base.consultant.ru/cons/cgi/online.cgi?req=doc;base=PNPA;n=5359

* Council Regulation (EU) No 960/2014.

* Council Regulation (EU) No 833/2014.

\section{Books/Articles/Official reports}

*The Agreement on the development of Piltun-Astokhsky and Lunsky oil and gas fields on the basis of production sharing ("The Sakhalin 2 PSA"), June 1994.

* 'The Chinese refused Gazprom the money to build the Power of Siberia pipeline', Vedomosti, 24 September 2014.

* 'The court has refused the Rosneft request on access to the Sakhalin Energy pipeline', Vedomosti, 19 February 2015.

* 'Draft decree for Gazprom to offer discount of up to 15\% of tariff service's price', Interfax CIS Oil \& Gas Weekly, 2 September 2014.

* Eastern Gas Programme (2007): Programme for development of the unified system for gas production, transportation and supply in east Siberia and Far East taking into account possible gas exports to the markets of China and other countries in the Asia-Pacific region, Minpromenergo Order No 340, 3 September 2007, http://base.consultant.ru/cons/cgi/online.cgi?req=doc;base=EXP;n=491137

* 'EU edges to economic sanctions on Russia but narrows scope', Reuters, 25 July 2015.

* FAS, 'Anatoly Golomolzin for unified tariff-setting on gas transportation', 24 October 2014, http://www.fas.gov.ru/fas-news/fas-news_35976.html

* FAS, 'Anatoly Golomolzin on the concept of developing the domestic gas market', 27 October 2014, http://en.fas.gov.ru/news/news_34029.html

* FAS, 'FAS has launched an investigation procedure against Gazprom at the Rosneft request', 3 December 2013, http://fas.gov.ru/fas-in-press/fas-in-press_39781.html

* FAS, 'FAS will determine the measures against Gazprom for non-participation in gas exchange trading', 3 March 2015, http://fas.gov.ru/fas-in-press/fas-in-press_40319.html

* 'FAS opened an infringement procedure against the Sakhalin 2 operator', Vzgliad, 14 August 2014.

${ }^{*}$ FTS Information Bulletin (in Russian), No 16 (246), 2 May 2007.

* FTS Information Bulletin (in Russian), No 11 (385), 26 March 2010.

* FTS Information Bulletin (in Russian), No 13 (579), 4 April 2014.

* FTS Report on 2013 results and mid-term tasks (in Russian), 2014.

* Gazprom, Gazprom Annual Report 2013,

http://www.gazprom.com/f/posts/60/660385/gazprom-annual-report-2013-en.pdf

* Gazprom, Gazprom Annual Report 2012, http://www.gazprom.com/f/posts/01/207595/annualreport-2012-eng.pdf

* Gazprom, Gazprom Annual Report 2009, http://www.gazprom.com/f/posts/05/285743/annualreport-2009.pdf

*Gazprom, Gazprom Annual Report 2008, http://www.gazprom.com/f/posts/71/879403/ae2008.pdf

* 'Gazprom has summed up its preliminary 2014 results', Gazprom, No 1-2, January-February 2005. 

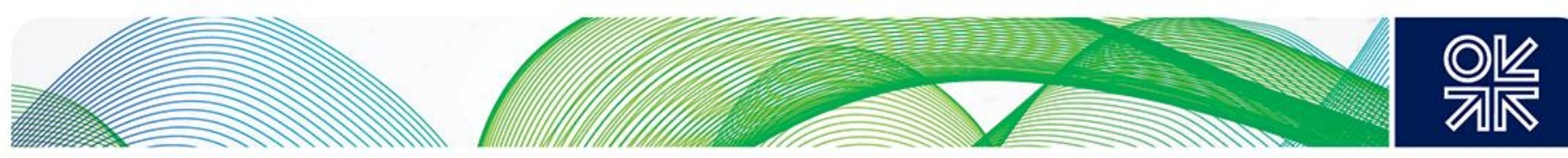

* Gazprom, Gazprom in Figures 2009-2013: factbook, http://www.gazprom.com/f/posts/55/477129/gazprom-in-figures-2009-2013-en.pdf

* Gazprom, Preliminary Bond Prospectus, 12 July 2013.

* Gazprom, 'In February 2014 Gazprom and Shell signed the memorandum-roadmap to prepare FEED documents for expansion', press release, 30 September 2014.

* Gazprom, 'The Power of Siberia pipeline construction has started', press release, 1 September 2014.

* Gazprom, 'Viktor Timoshilov: complex approach is necessary while planning and implementing major gas projects in the Far East', press release, 23 September 2014.

* Gazprom, 'Altai' (project description), http://www.gazprom.ru/about/production/projects/pipelines/altai/

* Gazprom , 'Sakhalin-Khabarovsk-Vladivostok' (project description) http://www.gazprom.ru/about/production/projects/pipelines/shvg/

* 'Gazprom begins building Power of Siberia gas pipeline, Interfax Russia \& CIS Oil \& Gas Weekly, August 28-September 3, 2014.

* 'Gazprom considers shelving Vladivostok LNG project', Financial Times, 10 October 2014.

* 'Gazprom refused Rosneft access to the Sakhalin 2 pipeline', 25 December 2013, http://lenta.ru/news/2013/12/25/refuse/

* 'Gazprom: Rosneft has asked the company for $4.5 \mathrm{bcm}$ of gas for its EOCC', TASS, 23 April 2014, http://itar-tass.com/ekonomika/1142121

* 'Gazprom suspends participation in trading platform over tax issue', Interfax, 27 January 2015.

* 'Gazprom will create a unified supply system for Russia', http://www.finam.ru/analysis/newsitem73FCB/

* 'Gazprom worried exchange trading in Russia will harm gas offtake in its contracts', Interfax Russia \& CIS Oil and Gas Weekly, 11-17 December 2014.

* The General Plan for Development of the Russian Gas Sector (draft) ("General Plan for Gas 2030") 2030,

http://www.energyland.info/files/library/112008/7579b56758481da282dd7e0a4de05fd1.pdf

* Henderson (2011): Henderson J., 'Domestic gas prices in Russia: towards export netback?' NG 57, OIES, 2011.

* Henderson (2014): Henderson, J, 'Commercial and political logic for Altai gas pipeline', OIES Energy Comment, December 2014.

* Henderson and Pirani (2014): Henderson, J. and Pirani, S. (eds), The Russian Gas Matrix: how markets are driving change, OUP 2014.

* Henderson and Stern (2014): Henderson, J. and Stern, J., 'The potential impact on Asian gas markets of Russia's Eastern gas strategy', OIES Energy Comment, February 2014.

* 'Issue of Chinese advance for power of Siberia up in air', Interfax Russia \& CIS Oil and Gas Weekly, 23 September 2014.

* 'Joint press conference with President of the Turkish Republic' (transcript, in Russian) http://www.kremlin.ru/news/47126

* Mann and Denton (2014): Mann, S. and Denton, R., 'The EU sanctions have now been published', 12 September 2014, http://www.bakermckenzie.com/sanctionsnews/

* The meeting of the Presidential Commission on strategy for energy sector development and environmental security (transcript, in Russian), 4 June 2014.

* 'Miller is ready to allow Rosneft access to the Trans-Sakhalin pipeline', 7 August 2014, http://infox.ru 

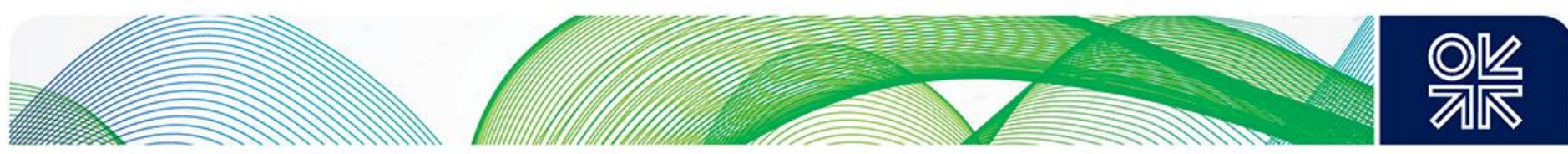

* 'Minenergo has not found access to the Power of Siberia pipeline', Vedomosti, 11 September 2014.

* Mitrova (2009): Mitrova, T., 'Russia, the CIS and Europe: gas trade and transit' in Pirani (ed) Russian and CIS Gas Markets and their Impact on Europe, OUP 2009.

* 'New draft of the General Plan for Gas to 2035 will be prepared by December', http://www.rbc.ru/rbcfreenews/20140227142124.shtml

* 'No place for Rosneft in the Sakhalin 2 pipeline', Vedomosti, 13 October 2014.

* 'Operating the trans-Sakhalin pipeline system', Pipelines International, March 2013. http://pipelinesinternational.com/news/operating_the_trans-sakhalin_pipeline_system/080362/ * Pirani (2009): Pirani, S. (ed) Russian and CIS Gas Markets and Their Impact on Europe, OUP 2009.

* Price list No 04-03-28-2005 'Internal calculated (wholesale) gas prices and internal transportation and storage tariffs for Gazprom entities', available at www.ngvrus.ru/docs/preyskurant.pdf, accessed 8 March 2014.

* Price list (additional) No 04-03-28-2009/1 'Internal calculated (wholesale) gas prices and internal transportation and storage tariffs for Gazprom entities', available at http://ipem.ru/images/stories/Files/gaz/2_conoco.pdf, accessed 8 March 2014.

* 'Putin will allow Rosneft in the trans-Sakhalin pipeline', 16 July 2014, http://lenta.ru/news/2014/07/16/pipe/

* 'Ransom for monopoly', Kommersant, 5 June 2014.

* 'Rosneft and Gazprom are divided by the pipeline' Kommersant, 13 May 2014.

* 'Rosneft, Gazprom not confirming out-of-court agreement on Sakhalin-2 pipeline - regulator', Interfax Weekly, 12 December 2014.

* 'Rosneft will get access to the Sakhalin pipeline' Kommersant, 7 August 2014.

* 'Rosneft will start preparations for construction of its EOCC petrochemical plant in August', Vedomosti, 22 July 2014, http://www.vedomosti.ru/companies/news/29266051/rosneft-vavguste-nachnet-podgotovku-k-stroitelstvu

* 'Russia could postpone gas pipe to China touted by Putin - sources', Reuters, 18 March 2015, http://uk.reuters.com/article/2015/03/18/russia-gas-china-idUKL6N0WI48420150318

* 'Russia's Rosneft may get access to Sakhalin 2 pipeline', TASS, 16 July 2014, http://en.itartass.com/economy/740857

* 'Sakhalin 2 project could pump gas for future Rosneft' LNG plant - Sakhalin governor', Interfax CIS Oil \& Gas Weekly, 22 September 2014. ,

http://www.interfax.com/newsinf.asp?pg=4\&id=538154

* Seliverstov and Gudkov (2012): Seliverstov, S. and Gudkov, I., "The Development of Electricity and Gas Networks in Russia" in Roggenkamp et al, Energy Networks and the Law: innovative solutions in changing markets, OUP 2012.

* Smirnova (2012): Smirnova, O., 'Anti-monopoly regulation of gas markets, presentation made at the round table 'Domestic gas market development: taxes, tariffs, prices and investments', forum 'Russia's gas - 2012', 20 November 2012 http://aeaep.com.ua/wpcontent/uploads/2014/09/Anty-monopol-noe-reguly-rovany-e-ry-nkov-gaza-Smy-rnova-FAS2012.pdf

* 'The start of gas transportation through the Power of Siberia pipeline has been delayed by two years', Vzgliad, 30 September 2014.

* Stern (2005): Stern, J., The Future of Russian Gas and Gazprom, OUP 2005.

* Stern (2014): Stern, J. (ed), 'Reducing European dependence on Russian gas', Working Paper NG 92, OIES, October 2014. 

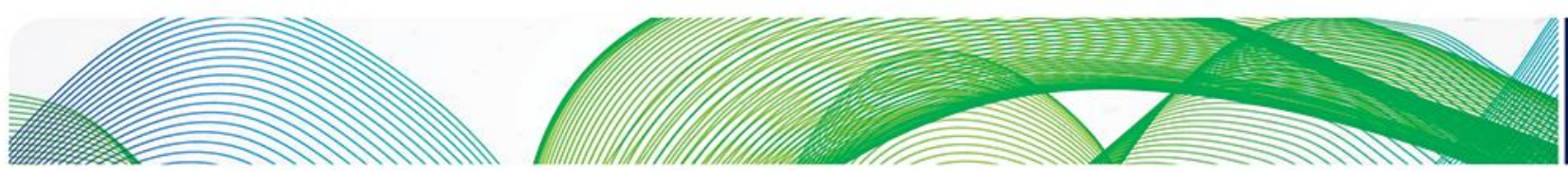

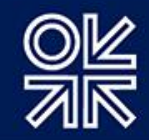

* Stern and Bradshaw (2008): Stern, J, and Bradshaw, M, 'Russian and Central Asian gas supply for Asia' in Stern, J (ed) Natural Gas in Asia: the challenges of growth in China, India, Japan, and Korea, OUP 2008.

* Stern, Pirani and Yafimava (2015): Stern, J., Pirani, S. and Yafimava, K., 'Does the cancellation of South Stream signal a fundamental reorientation of the Russian gas strategy?', OIES Energy Comment, 2015.

* Yafimava (2013): Yafimava K., 'The Third Energy Package and the Gas Target Model: contentious issues inside and outside the EU', Working Paper NG 75, OIES 2013. 